NBER WORKING PAPER SERIES

\title{
FIRM-SPECIFIC RESOURCES, FINANCIAL-MARKET DEVELOPMENT AND THE GROWTH OF U.S. MULTINATIONALS
}

\author{
Susan Feinberg \\ Gordon Phillips \\ Working Paper 9252 \\ http://www.nber.org/papers/w9252
NATIONAL BUREAU OF ECONOMIC RESEARCH
1050 Massachusetts Avenue
Cambridge, MA 02138
October 2002

\begin{abstract}
We wish to thank Wayne Ferson, Robert McDonald, Vojislav Maksimovic, Raymond Mataloni, Oguzhan Ozbas, John Popham, Antoinette Schoar, Lemma Senbet, Scott Shane, Peter Wysocki, Bernie Yeung, William Zeile and seminar participants at Boston College, the Center for Economic Studies, Department of Commerce, MIT finance and organizations seminars and the University of South Carolina for helpful comments. The statistical analysis of firm-level data on U.S. multinational corporations reported in this study was conducted at the International Investment Division, Bureau of Economic Analysis, United States Department of Commerce, under arrangements that maintained legal confidentiality requirements. Views expressed are those of the authors and do not necessarily reflect those of the Department of Commerce or the National Bureau of Economic Research.
\end{abstract}

(C) 2002 by Susan Feinberg and Gordon Phillips. All rights reserved. Short sections of text, not to exceed two paragraphs, may be quoted without explicit permission provided that full credit, including $(\mathrm{C}$ notice, is given to the source. 
Firm-Specific Resources, Financial-Market Development and the Growth of U.S. Multinationals

Susan Feinberg and Gordon Phillips

NBER Working Paper No. 9252

October 2002

JEL No. F1, G3

\section{ABSTRACT}

We study the resource allocation decisions of U.S. multinational corporations (MNCs). We examine how established MNCs grow across countries and how firm-specific resources and host country financial-market development influence MNC growth. We find evidence of intra-firm tradeoffs to growth in MNCs that have limited organizational capital and high R\&D, and MNCs with low external and internal financing. In countries with less developed capital markets, we find significant within-MNC trade-offs to growth between affiliates and their U.S. parents. These trade-offs diminish over time as local capital markets develop. Our evidence indicates that access to financing and organizational capital are important resources for MNC affiliate growth.

\author{
Susan Feinberg \\ R.H. Smith School of Business \\ University of Maryland \\ Van Munching Hall \\ College Park, MD 20742 \\ feinberg@glue.umd.edu
}

\author{
Gordon Phillips \\ R.H. Smith School of Business \\ University of Maryland \\ Van Munching Hall \\ College Park, MD 20742 \\ and NBER \\ gphillips@rhsmith.umd.edu.
}


Multinational corporations are increasingly an important source of production and employment in industrialized countries (OECD, 1999). Existing research shows that U.S. multinational corporations (MNCs) have higher accounting profits and higher stock market valuations, higher advertising and R\&D, and higher Tobin's qs than do firms that only produce and sell domestically. ${ }^{1}$ However, we know little about what influences the international growth and operating decisions of established MNCs across networks of affiliates. Despite the obvious importance of MNCs' resource allocation choices, much of the research on MNC expansion has focused primarily on initial foreign investment decisions. ${ }^{2}$ Similarly, policy makers have focused more on luring initial foreign investments than on creating environments in which existing MNC subsidiaries can become more globally competitive.

Our research focuses on the importance of firm- and market-specific factors to MNCs' allocation of resources across networks of affiliates. We draw on the theory of the conglomerate firm and its resource allocation decisions across markets to study the growth of MNCs as networks of affiliates. We first study whether there are geographic trade-offs to growth across affiliates (and parents) within the MNC, similar to the intra-industry trade-offs to growth in U.S. conglomerate firms shown in Maksimovic and Phillips (2002). ${ }^{3}$ Second, we examine the extent to which these trade-offs vary systematically based on MNC and country characteristics.

We wish to determine how the growth of MNC affiliates is related to firm-specific factors shown by previous research to be important for the emergence of multinational operations. ${ }^{4}$ For example, we examine how growth differs among affiliates of MNCs that are more R\&Dintensive, since R\&D indicates the presence of knowledge assets. We also study variations in growth among affiliates that differ in their access to capital. The market-specific factors that we examine are capital market development and host country contracting effectiveness.

We test our predictions using disaggregated panel data from the U.S. Department of Commerce on 8,106 foreign affiliates of 862 U.S. MNC parent companies in 41 countries.

\footnotetext{
${ }^{1}$ See Vernon (1971), Dunning (1973), Kim and Lin (1986), and Morck and Yeung (1991). Errunza and Senbet $(1981,1984)$ show that the value of multinationality increases with the extent an MNC sells overseas. ${ }^{2}$ See Baldwin (1988), Dixit (1989), and Wheeler and Mody (1992).

${ }^{3}$ Denis, Denis and Yost (2002) document the extent of global diversification by U.S. firms and extend work by Bodnar, Tang and Weintrop (1999) in studying the valuation effects of MNCs in the stock market.

${ }^{4}$ See Buckley and Casson (1976), Dunning (1973), Ethier (1986), Helpman (1982), and Rugman (1981).
} 
An important feature of this data is that it contains detailed information about foreign affiliates' trade and financing both within the MNC and in local markets. Thus, we can directly examine how internal financial and product markets affect MNC growth. Previous literature on U.S. conglomerate firms has only been able to indirectly infer the extent of internal capital and product market flows. ${ }^{5}$

We examine two central questions about MNC growth. First, do MNC affiliates grow together, or do they compete for scarce resources from their U.S. parents, as parents choose to allocate resources based on affiliates' relative efficiency and demand growth? We refer to this latter case as within-MNC trade-offs to growth.

To address this first question, we draw on theories of the MNC and theories of conglomerate firms that focus on trade-offs in the allocation of resources across multiple markets. Domestic conglomerate firms allocate their scarce resources according to the returns to scale in the use of these resources and to the demand growth in their markets. We therefore examine whether there are similar trade-offs among divisions of MNCs, and whether these trade-offs vary for MNCs that are more R\&D intensive or have potentially differential access to financing.

Second, we examine whether MNCs' resource allocation decisions vary with differences in financial-market and institutional development in the affiliates' local markets. Although recent research examines the impact of financial market development and the legal environment on country economic development and the growth of domestic firms ${ }^{6}$, we know little about the impact of financial markets on the growth of established MNC affiliates.

Using panel data on the entire population of U.S. MNCs - disaggregated at the individual foreign affiliate level for each MNC parent - our empirical analysis demonstrates that MNC growth is strongly related to affiliate efficiency. The efficiency of an MNC affiliate, relative to other same-industry affiliates of a given U.S. parent and relative to other same-industry affiliates in the same country, strongly predicts the affiliate's growth, especially when there is demand growth in the affiliate's local market.

We also find evidence of trade-offs across affiliates within MNCs, particularly for MNCs

\footnotetext{
${ }^{5}$ For evidence on investment patterns by diversified firms see Shin and Stulz (1998), Scharfstein (1998), Rajan, Servaes and Zingales (2000), and Maksimovic and Phillips (2002).

${ }^{6}$ See the evidence provided in King and Levine (1993), Levine (1997), LaPorta, Lopez de-Silanes, Shleifer, and Vishny (1997), Demirguc-Kunt and Maksimovic (1998), Rajan and Zingales (1998), and Wurgler (2000).
} 
with small affiliate networks. Indeed, trade-offs to growth in small MNC networks exist regardless of whether the $\mathrm{MNC}$ is $\mathrm{R} \& \mathrm{D}$-intensive. In contrast, we do not find evidence of trade-offs to growth in MNCs with large networks. R\&D and access to capital may enable large MNCs to grow without extensive trade-offs across affiliates. Our evidence suggests that smaller MNCs have limited financial and organizational resources. These limitations can cause an individual affiliate's growth to be affected by demand growth in other markets where the MNC has efficient affiliates.

We find that a country's capital market development affects MNC affiliate growth. In countries with less-developed financial markets, we find that affiliates of MNCs with small networks are constrained in their growth when they rely more on their parents for financing.

Our results also show that in countries with less-developed financial markets, affiliate growth increases with improvements in host-country contracting effectiveness. This result is particularly strong for affiliates that conduct a larger proportion of their transactions with local firms. We also find that in countries with rapidly developing financial markets, trade-offs to growth within affiliate networks diminish over time. Thus, better contracting effectiveness and growing financial markets may signal the potential for rapid future development and enable local firms to transact more business with MNC affiliates.

Our paper makes two significant contributions. First, we provide evidence on how MNCs grow across affiliate networks when they must cope with potentially scarce firm-specific resources. Although the firm-specific resources that we examine (R\&D and access to capital) may be important to the initial emergence of MNCs, these resources have not been examined in the context of their importance to subsequent MNC growth.

Second, our paper also provides evidence on how MNC growth is affected by hostcountry financial and institutional development. We find a positive relation for the growth of established MNC affiliates and higher contracting effectiveness. Trade-offs within MNCs diminish over time in countries with rapidly developing financial markets.

The paper proceeds as follows. In the next section, we discuss the models of resource allocation that provide the framework for our empirical analysis. Section II describes the data and econometrics, and Section III presents the empirical results and discussion. Section IV concludes. 


\section{A Framework for MNC Resource Allocation}

The common element in theories of the MNC is the idea that MNCs are formed because there are firm-specific assets or scarce resources that cannot (or cannot except at a high cost) be licensed or contracted in arms-length transactions to other firms (Buckley and Casson, 1976; Dunning, 1973; Ethier, 1986; Helpman, 1984; Rugman, 1981). Although Helpman's work explains the emergence of the MNC, it does not describe how a multi-plant, multicountry firm can grow, once it has established international production.

These scarce resources, the firm-specific advantages such as organizational ability, knowledge assets developed through R\&D, and superior access to capital, generate multi-plant scale economies that firms exploit internationally to take advantage of differences in factor endowments between countries. The extent to which these scarce resources can be utilized across an MNC's international network depends on the nature of the resource and the returns to scale in its exploitation.

Our research investigates whether MNC growth involves resource allocation trade-offs across affiliates in different countries. We examine whether resource trade-offs exist within MNCs, and if the trade-offs vary based on the type of scarce resources that MNCs possess. Finally, we look at how characteristics of the countries in which the MNCs operate (in particular financial market and institutional development) affect MNC growth and intrafirm trade-offs.

Generalizing from the Maksimovic and Phillips (2002) study on the inter-industry resource allocation decisions of domestic conglomerates, we can make inferences about MNC growth. From a steady state, MNC affiliates in particular countries will grow when they receive a positive change in demand. This change in demand can come from either an increase in real GDP or a beneficial change in exchange rates. More efficient affiliates will be better positioned to grow in response to positive demand growth in their local markets.

Across multiple countries, an MNC will grow its affiliates until the value of a marginal investment is equalized across the countries in which it operates. The extent to which a given affiliate's growth is affected by demand growth in the countries of the MNC's other affiliates will depend on the extent to which the MNC's scarce resource faces locally constant or decreasing returns to scale. If the exploitation of the scarce resource faces constant or locally constant returns to scale, a positive change in demand in one market should have no 
effect on the growth of affiliates in other markets (with increasing returns to scale, a positive change in demand should have a positive effect on affiliates in other markets). However, when the scarce resource faces decreasing returns to scale, the MNC may face trade-offs to growth across markets. With decreasing returns to scale in the use of the scarce resource, and therefore trade-offs to growth, an MNC will reallocate resources in favor of countries with relatively higher growth where it has efficient affiliates.

Our tests of MNC resource allocation thus focus on the relative efficiency and demand growth of MNC units. Empirically, this implies testing for trade-offs to growth using interactions between relative efficiency and demand. In contrast, other studies of U.S. conglomerate firms' domestic resource allocation do not condition on the relative efficiency of business units (Lamont (1997), Scharfstein (1998) and Shin and Stulz (1998)).

When we apply the Maksimovic and Phillips (2002) model to MNCs, we predict that an MNC will grow less in one affiliate when the opportunity cost of allocating its scarce resources to a different affiliate is higher. Thus, the growth and efficiency of a particular affiliate may affect an MNC's decision to grow in other affiliates or in the parent itself.

The theories of resource allocation decisions under differing assumptions about returns to scale in the use of scarce resources suggest tests of the following hypotheses:

Hypothesis 1: MNC Affiliate growth follows a specific pattern:

The growth of an affiliate (of a given MNC parent) in a given country is

(i.) higher, the more efficient the affiliate is and the greater the demand growth in its local market;

(ii.) lower (higher), when the $M N C^{\prime}$ 's other affiliates have higher (lower) relative efficiency and greater relative demand growth, and the MNC faces decreasing returns to scale in the use of its firm-specific scarce resources-either organizational capital, R\&D, or access to financial capital.

If the scarce resources face constant or increasing returns to scale, the growth of an affiliate in a given country will not be diminished by demand growth in other countries where the MNC has efficient affiliates.

We also expect that trade-offs to growth within the MNC will vary according to the type of scarce resource the MNC possesses. We examine the variation in trade-offs to growth for 
MNCs that differ in their R\&D-intensity and access to financing. In addition, an MNC's organizational capital, for which we use the size of its affiliate network as a proxy, should affect intra-firm trade-offs to growth, given organizational resources should be higher for MNCs that manage complex, geographically dispersed networks.

MNCs that compete on the basis of knowledge assets developed through R\&D are likely to grow with fewer intra-firm trade-offs. Since knowledge assets can be exploited throughout the MNC's network of affiliates with constant or increasing returns to scale, these may not face the same increasing costs as firm resources such as organizational talent or access to financial capital. Indeed, a key reason in the literature for the emergence of MNCs is the "public good" nature of knowledge-based resources and the multi-plant economies of scale they generate. (Helpman, 1984)

However, we expect that an MNC's organizational capital will affect its ability to maximize the benefits of its R\&D. Firms with greater organizational capital may face lower costs of attaining larger size, as emphasized by Lucas (1978) and Williamson (1975), and organizing across multiple markets, as in Maksimovic and Phillips (2002). Therefore, it is likely that larger firm size, generally, and larger affiliate networks for MNCs, signals the presence of greater organizational capital. As regards the exploitation of knowledge assets, evidence in the U.S. by Himmelberg and Petersen (1994) show that small, high-R\&D firms in the U.S. face financial/organizational constraints that limit their ability to maximize the benefits of R\&D.

Organizational capital is perhaps even more critical to an MNC's ability to transfer knowledge assets across dispersed international networks of affiliates. Smaller MNCs might not have the financial and/or organizational capital necessary to exploit $R \& D$ across their networks. Therefore, we examine whether trade-offs to growth across an MNC's affiliates vary by both $R \& D$ and size. If smaller firms face organizational constraints in exploiting knowledge assets created through $R \& D$, we expect that among high-R\&D MNCs, withinfirm trade-offs to growth should be larger when affiliate networks are small. Thus, a positive change in demand in a particular market makes it more valuable for high-R\&D MNCs with small affiliate networks to reallocate limited resources to that market and away from other markets.

We summarize these predictions in the following hypothesis: 
Hypothesis 2: The importance of knowledge-based resources.

(i.) If MNCs face constant or increasing returns to scale in the international transfer of knowledge-based resources, we expect few or no intra-MNC trade-offs to growth in RED-intensive MNCs (relative to low-R\&D MNCs).

(ii.) If financial and/or organizational capital are important in the exploitation of knowledge assets and are scarce for smaller firms, we expect larger trade-offs to growth in R\&D-intensive MNCs with small affiliate networks vs. REDD-intensive MNCs with large affiliate networks.

Access to financing is often hypothesized to be an important MNC resource. Researchers have argued that MNCs and their foreign affiliates have access to lower cost debt financing (Shapiro, 1978; Reeb, et al., 2001).

The issue of whether access to financing faces constant or decreasing returns will have implications for trade-offs to growth across affiliates within the MNC similar to those for knowledge assets. If financial capital is a scarce resource that faces increasing costs, we expect MNCs will allocate resources into markets where they have efficient affiliates and increasing local demand, and out of markets where affiliates are less efficient or have negative demand growth. By contrast, if affiliates can obtain high-quality financing regardless of their efficiency relative to other affiliates of the same MNC (or to the parent itself), we would not expect to see intra-firm trade-offs to growth.

In our context, if MNC network size is a signal of superior organizational capital, then larger firms may be able to access capital more easily. Hence, for MNCs with superior access to capital (for which we use local and parent financing as proxies), larger networks should further reduce the trade-offs to growth across markets.

We summarize these predictions in the following hypothesis:

Hypothesis 3: The importance of financial capital as a firm-specific resource.

(i.) If MNCs face a constant cost of accessing financial capital, we expect few or no intra-MNC trade-offs to growth in MNCs based on their extent of financing from both local markets and U.S. parents. 
(ii.) If MNCs face an increasing cost of accessing financial capital, we expect higher intra-MNC trade-offs to growth. If size is important in accessing capital markets, we expect the largest finance-related trade-offs to growth for affiliates of MNCs that have small affiliate networks.

Finally, we examine how financial market development and host-country contracting effectiveness influence MNC affiliate growth. Access to financing may be a more important MNC resource in an international context because host-country firms without well-developed capital markets may have difficulty obtaining the financing to grow.

For U.S. MNCs, most MNC affiliate borrowing is in local markets. Thus, the problem of limited local access to finance for MNCs with smaller networks is likely to be more acute in less developed capital markets. If local access to capital is limited, affiliates may rely more their U.S. parents to finance local operations. Under this scenario, we might expect affiliate growth to increase with MNC parent financing. However, if parent financing is limited, then reliance on parent financing may also increase trade-offs within the MNC when the parent's own opportunities, or opportunities in other efficient affiliates, improve. Again, we expect these trade-offs to be more pronounced for MNCs with small affiliate networks in countries where local financial markets are less developed.

We summarize these predictions in the following hypothesis:

Hypothesis 4: The importance of local financial market development For $M N C$ affiliates in less developed financial markets, we expect that:

(i.) affiliate growth will increase with parent financing.

(ii.) trade-offs to growth within the MNC will increase with dependence on parent financing, assuming an increasing cost of accessing external finance.

(iii.) if organizational capital is important to an MNC's ability to obtain local financing, trade-offs to growth will be larger in MNCs with small affiliate networks.

The ability to internalize contracts is considered to be a key advantage of MNCs, particularly MNCs that are located in countries with weak domestic institutions and/or less developed capital markets (Caves, 1982). Thus, improvements in host-country contracting 
effectiveness could diminish this advantage, and impede MNC growth. However, for MNC affiliates that transact more with local firms (versus transacting more within the MNC), host-country institutional development, especially improvements in contracting effectiveness, should increase affiliate growth, since the cost of doing business with local firms declines. We expect that this relation will be particularly strong in countries with less developed capital markets.

We summarize these predictions on the effect of local institutional development/contracting effectiveness in the following hypothesis.

Hypothesis 5: The importance of institutional development.

For MNC affiliates in less developed financial markets, we expect the following:

(i.) Affiliate growth will increase with improvements in host country contracting effectiveness-for affiliates that transact more with local firms.

(ii.) Better host country contracting effectiveness will have little or no effect on the growth of affiliates that conduct a high volume of purchases and sales within the $M N C$, as they can internalize contracting costs.

In the next section, we describe the data, variables and estimation techniques we use to test our hypotheses, and we present results in section III.

\section{Data and Methodology}

\section{A. Data}

We obtain our data set from the Benchmark and Annual Surveys of U.S. Direct Investment Abroad, which is administered by the Bureau of Economic Analysis (BEA), United States Department of Commerce. These surveys are the most comprehensive data available, with income statement, balance sheet, and employment data, on the activities of U.S.-based MNCs and their foreign affiliates. For this study, we use the BEA data disaggregated at the individual foreign affiliate level for each MNC from 1983-1996. The BEA data includes foreign affiliates that report sales in more than 120 two- to-three-digit industry codes across multiple countries. The affiliate data can also be linked to data on the U.S. parents.

We use data on both affiliates and parents in this study, and include only wholly-owned affiliates. This last criterion affects only 3,620 observations in our data set and does not 
affect our results. Our final regression sample includes 34,384 affiliate-year observations on 8,106 affiliates in 41 countries of 862 U.S. parents. We present more specific details of the BEA data and how we construct the sample in the data appendix to this paper.

\section{B. MNC-Specific Variables}

Our key predictions focus on the relation between affiliate relative efficiency and affiliate growth. Our predictions relate to the interaction between affiliate relative efficiency and demand growth and intra-MNC trade-offs, which we measure by the interaction of the efficiency of the parent and other affiliates in the MNC network and their relative demand growth. For clarity, we refer to the focal affiliate, about which our predictions focus, as affiliate $i$. Our discussion below proceeds as follows. We first describe our dependent variable then discuss the efficiency and efficiency* ${ }^{*}$ demand growth interaction variables. Next, we describe our measures of MNC resources (R\&D, access to finance, organizational capital). Finally, we discuss our measures of financial market development and contracting effectiveness, and conclude with a description of the control variables in our model. ${ }^{7}$

\section{B1. Dependent Variable:}

Our dependent variable, Empch $g_{i j c p}$, is the log change in employment of affiliate i (the "focal affiliate") in industry $j$ in country $c$ of U.S. MNC parent, $p$, from time $(t-1)$ to $t$. We use a log change to mitigate heteroskedasticity, because the number of employees (and change in employment) varies considerably in the sample of affiliates. We use employment change as a measure of growth since it is the only local quantity-based input variable we can observe directly, and, unlike variables such as assets or sales, it is not directly affected by exchange rates.

We also estimate the model using change in affiliate real assets as a robustness test. We find similar results and discuss these results along with other robustness tests in the results section.

\section{B2. Efficiency of Foreign Affiliates and MNC Parents:}

We test our key predictions using interaction variables between affiliate and parent efficiency and demand growth (as captured by GDP growth). Under Hypothesis 1, we expect that the growth of affiliate $i$ (as measured by Empch $g_{i j c p}$ ), will depend on the interaction

\footnotetext{
${ }^{7}$ All MNC variables in our regressions are lagged. All dollar variables are expressed in 1982 dollars, using industry-specific price deflators from the BLS. We note that all foreign affiliate data reported to the BEA is already expressed in current U.S. dollars.
} 
between its own relative efficiency and the GDP growth in its local market. In addition, if an MNC faces decreasing returns to scale in the use of its firm-specific resources, we expect that other affiliates' relative demand growth interacted with their relative efficiency will be negatively associated with the growth of affiliate $i$. The negative relation arises because the MNC allocates resources away from affiliate $i$ when its other affiliates have more attractive growth opportunities.

We calculate four measures of efficiency, two for the focal affiliate, a third for the other "sibling" affiliates of the MNC and the fourth for the U.S. MNC parent. All four efficiency measures use the same basic definition of efficiency. These measures can be interpreted as labor value-added, and all are industry and year adjusted. We discuss these measures in detail in the data appendix.

We calculate two direct measures of efficiency for affiliate $i$. First, we calculate affiliate $i$ 's within-MNC (industry and year adjusted) efficiency. This variable captures affiliate $i$ 's efficiency relative to other same-industry affiliates within affiliate $i$ 's MNC. We calculate our second measure of affiliate $i$ 's efficiency relative to other MNC affiliates in the same industry in the same country-year. Our third measure of affiliate efficiency, other affiliate efficiency, is a weighted average of the efficiency of all the affiliates of a given MNC parent (excluding affiliate $i$ ). Our final measure of efficiency is the industry-year-adjusted efficiency of affiliate $i$ 's U.S. parent. We note that we expect both measures of affiliate $i$ 's efficiency to be positively associated with affiliate $i$ 's growth. Our main predictions for other affiliate and U.S. parent efficiency center around the interactions between these efficiency variables and the other affiliates' and the parent's relative demand growth.

\section{Interaction Variables:}

We use three key interaction variables to capture potential trade-offs within the MNC. First, we multiply affiliate i's within-MNC efficiency by local demand growth, which we measure as the log change in country $c$ 's real GDP from time $(t-1)$ to $t$. We use the change in GDP (rather than changes in real exchange rates) to measure local demand growth, since the average proportion of affiliate sales in the local market is over 75 percent. ${ }^{8}$ Second, we multiply other affiliates' relative efficiency by their relative demand growth. We measure other affiliates' relative demand growth by taking the sales-weighted average of the one-

\footnotetext{
${ }^{8}$ The change in real exchange rates was used in the interaction variables in an earlier version of this paper. It is still included as an independent variable.
} 
period real GDP changes for all affiliates (other than affiliate $i$ ) of a given parent, less affiliate i's own demand change. Finally, we multiply the U.S. parent's efficiency by the parent's relative demand growth. The parent's relative demand growth is calculated as the U.S. parent's one-period real GDP change (change in U.S. real GDP from (t-1) to $t$ ) less affiliate $i$ 's one-period real GDP change.

\section{B3. Types of MNC Firm-Specific Resources:}

We examine three different types of firm-specific resources/characteristics: knowledge assets, as captured by R\&D; access to financial capital; and organizational capital. As detailed in Hypotheses 2 and 3, we predict that the more these resources are scarce and face decreasing returns to scale, the more trade-offs there will be across affiliates within MNCs.

\section{Research and Development}

We use the (lagged) amount of R\&D conducted by U.S. MNC parents to classify MNCs into high and low R\&D firms. We do so by splitting the sample of parent firms into two sets based on whether their R\&D-to- sales ratio is above or below the median parent R\&Dto-sales ratio by year. The number of affiliates in each of these subsamples is different as parents above and below the median have differing numbers of affiliates.

\section{Financial Resources: Affiliate Financing}

We use BEA affiliate data on the (lagged) amount of debt financing, from local sources and the U.S. parents, as proxies for the affiliate's access to capital. Debt financing is a good proxy for access to capital as most financing (both provided by its parents and from local markets) for affiliates is in the form of debt capital. In addition as reported in Table I, debt-to-asset ratios for affiliates are very high, 53.8 percent on average. These ratios are substantially higher than debt-to-asset ratios for U.S. firms reported on COMPUSTAT, which average only 27.2 percent over the same time period. Ideally we would like additional information on paid in equity capital but this information is only available for the subset

of incorporated affiliates (typically the larger affiliates). If access to financial capital faces constant returns for the MNC, we expect to see few or no intra-firm trade-offs to growth for MNC affiliates based on the extent of total debt (local and parent) financing.

3. Organizational Resources: Affiliate Network Size

We use the (lagged) number of affiliates of an MNC parent to capture an MNC's organizational capital. In using this proxy, we assume that MNCs that operate more extensive 
networks have developed the skills, routines, and general organizational ability necessary to manage the network. We examine whether affiliates from larger MNC networks have fewer trade-offs to growth.

\section{B4. Affiliate Sales within the MNC:}

To measure affiliate $i$ 's intra-firm transactions, we use the (lagged) ratio of affiliate total trade (imports and exports) with other divisions of the MNC divided by affiliate $i$ 's sales. By definition, affiliates that conduct a higher proportion of transactions within the firm transact less with local firms and are relatively sheltered from the host country institutional environment. We predict that improvements in a country's contracting effectiveness will be positively associated with the growth of affiliates that conduct a smaller volume of purchases and sales within the MNC, because the affiliates internalize contracting costs. We also use this variable as a control in all our regressions. We expect that affiliates that have been established solely to produce an input to the U.S. parent's production will show little or no response to conditions in its local market (and potentially to its own efficiency).

\section{Country-Specific Financial and Institutional Variables}

In our initial analysis of the effects of financial market and institutional development, we first examine the relation between affiliate growth, within-MNC trade-offs, and hostcountry stock market capitalization. Second, we examine whether the impact of contracting effectiveness differs in countries with high versus low stock market capitalization. Third, we look at how changes in the development of capital markets over a 12-year period affect MNC growth.

We use several variables as proxies for the level of a country's capital market and institutional development. We construct these variables by using data from the IMF International Financial Statistics Yearbook, the Annual IFC Emerging Stock Markets Fact Book, and IRIS. We use the (real) size of the capital markets at the end of the year divided by real GDP. We also examine the robustness of our results to an alternative measure of capital market development. We use a measure of bank credit availability (claims on the private sector by deposit money banks divided by GDP). For institutional development, we use an annual measure of "contracting effectiveness" from IRIS Country Risk Guide, which is available from 1982-95. ${ }^{9}$ This variable is an ordinal measure ranging from zero to ten.

\footnotetext{
${ }^{9}$ This data was first used in Clague, Keefer, Knack and Olson (1996). It has also been used in an
} 
We calculate the change in market capitalization from the average of the 1983-1986 period to the average of the 1993-1996 period. To avoid any specific year driving our results, we use a three-year average for the beginning and ending periods. If MNCs are focusing on countries that have the potential for long-term growth, we expect that higher growth in capital-market development will be associated with higher MNC affiliate growth.

\section{Control Variables}

We control for affiliate size by using the log sales of affiliate i at ( $t-1)$. Our other control variables include all main effects for variables that are interacted. In other words, although our predictions focus on the interaction terms, we present the efficiency and demand change variables in our model separately.

Next, we use several country control variables. Unless otherwise indicated, all our regressions include country fixed effects to control for unobserved time-invariant country differences, such as factor endowments or the distance from the U.S., that might influence our results.

In addition to the one-period real GDP change, we use the following country control variables in our model:

(1.) Change in real exchange rate: We measure the change in the exchange rate in country $\mathrm{c}$ as the log change in the real trade-weighted CPI-based exchange rate from time $(t-1)$ to $t .{ }^{10}$ Given negative changes represent real depreciations and thus positive exchange rate changes, a negative sign on this variable indicates a "positive" relation.

(2.) Long run GDP growth: We measure long-run GDP growth as the log change in real GDP from time $(t-5)$ to time $t$. Holding affiliate efficiency constant, we expect that long-run growth in country c will be positively associated with affiliate growth.

(3.) Taxes: We also control for country-level tax effects by including an effective tax variable that varies by country and year. Our effective tax rate is the median value, for each country and year, of affiliate taxes paid divided by taxable income. See Desai (1999) for an explicit treatment of tax effects.

international asset pricing paper by Lombardo (2001), who was kind enough to provide us with this data.

${ }^{10}$ We are grateful to Anthony Turner of the IMF for providing us with real exchange rate data. More information on the construction of the real exchange rate series used here can be found in Tuner and Golub (1997). We also ran the regressions using a real unit-labor based real exchange rate series also from Tuner and Golub. The results (not reported here) did not differ from those obtained using the CPI-based real rate, and the CPI-based rate is a longer series. 
(4) We control for time using a trend, which we calculate as year-1983.

\section{E. Estimation}

We estimate the following panel regression model:

$\mathrm{Y}_{i(t-(t-1))}=\beta_{o}+\beta_{1} \mathrm{X}_{i(t-1)}+\beta_{2} \mathrm{Z}_{i(t-(t-1))}+\mathrm{C}_{i}+\tau_{t}+\mathrm{n}_{i t} i=1,2, \ldots \mathrm{N} ; t=1,2, \ldots 14$

where $\mathrm{Y}_{i(t-(t-1))}$ is the log change in employment of affiliate $i . \mathrm{X}_{i(t-1)}$ is a matrix of lagged firm-specific variables and interactions including two measures of affiliate $i$ 's efficiency (one relative to affiliate $i$ 's MNC-industry, the other relative to affiliate $i$ 's country-industry), the efficiency of other affiliates in affiliate $i$ 's network, the efficiency of affiliate $i$ 's U.S. parent. $\mathrm{X}_{i(t-1)}$ also includes the key interaction variables: affiliate $i$ 's efficiency interacted with its demand growth and other affiliates' efficiency and U.S. parent efficiency interacted with their relative demand growth, and affiliate $i$ 's $\log$ sales. $Z_{i(t-(t-1))}$ is a matrix of country variables including a one- and five-year GDP change, a country-year tax rate and the change in the exchange rate. $\mathrm{C}_{i}$ is a vector of country fixed effects and $\tau_{t}$ is a time trend.

$\mathrm{n}_{i t}$ is the error term, which consists of two components: $\mathrm{n}_{i t}=\mathrm{u}_{i}+\mathrm{e}_{i t}$, where $\mathrm{u}_{i}{ }^{\sim} \mathrm{N}(0$, $\left.\sigma_{u}^{2}\right)$ is a vector of unobserved time-invariant affiliate-specific characteristics (affiliate random effects) which are i.i.d. over time and across firms. $\mathrm{e}_{i t}$ is assumed to vary over time and across firms.

We estimate Equation (1) by using a GLS (random effects) estimator on an unbalanced panel. We use GLS rather than fixed effects so that we can include time-invariant country effects in our model. A random effects estimator is also more efficient than fixed effects when some variables are at the industry level with firm level panel units (Moulton, 1986). As a robustness check of our regression model, we added industry dummy variables to the basic specification. We found no qualitative differences for this specification, and thus only report random effects estimates with country fixed effects. The results of our regression models are reported in Tables 4-10 and will be discussed in detail in the next section.

\section{Results}

\section{A. Sample Summary Characteristic}

Table I summarizes the key firm- and market-specific variables that we examine. We present summary statistics in this table for the whole sample and also by MNC R\&Dintensity. 


\section{Insert Table I - MNC Affiliate Characteristics}

Panel A of Table I shows that high R\&D parents have larger affiliate networks, and the individual affiliates are larger in terms of sales. Table 1 also shows that average affiliate debt is significantly higher from local (rather than parent) borrowing, despite the affiliates being part of a U.S. MNC. However, affiliates of high-R\&D MNCs use significantly more debt from the parent and less debt from local borrowing. Overall, affiliates of high R\&D MNC parents have less debt financing. High R\&D MNC affiliates also internalize more of their trade. The within-MNC trade of high R\&D MNC affiliates trade is over 10 percent higher than in low R\&D MNCs.

Panel B of Table I shows characteristics of the countries in which the U.S. MNCs operate. Inspection of the results indicates that MNCs primarily operate in the highest stock market capitalization countries. These countries also have higher one- and five-year real GDP growth rates.

\section{Insert Table II - U.S. MNC Foreign Affiliate Characteristics and R\&D}

Table II breaks out the statistics by MNC R\&D and network size. We find that the characteristics of high R\&D MNCs documented in Table I are more pronounced for MNCs with small networks of affiliates. High R\&D MNCs with small networks borrow less overall and borrow more from their parents than all other groups. High R\&D MNCs with large networks borrow the next lowest overall and the second highest from their parents. High R\&D MNCs also have the highest percentage of their sales within the MNC. These findings indicate that $\mathrm{R} \& \mathrm{D}$ is a resource that is hard to collateralize and borrow against in the external market. Further, R\&D appears to be a firm-specific resource that is harder to buy or sell in arms-length contracts as affiliates of high R\&D MNCs have a significantly lower fraction of their sales to local parties.

Table III presents affiliate growth by the initial efficiency of the affiliates, using affiliate $i$ 's efficiency relative to other MNC affiliates in the same industry, in the same countryyear. Efficiency quartiles are determined by the median of the affiliates' initial efficiency for the first three years they appear in the sample. We then track the affiliates' employment growth for the next nine years until 1996, or until they drop out of the sample. In Panel A, we present affiliate growth rates for the top and bottom quartiles of initial efficiency. In 
Panel B, we focus on those firms in the top two and bottom two quartiles of capital market development. Capital market development quartiles are determined by ranking countries by their stock market capitalization in each year.

\section{Insert Table III - MNC Allocation of Resources by Affiliate Efficiency}

In Table III, Panel A shows that affiliates with the highest initial efficiency had the highest average growth rate over all subsequent periods. Panel B shows that the higher growth of high-efficiency affiliates is more pronounced in countries with low capital market development. The affiliates in efficiency quartile four (the highest efficiency quartile) grow 22.19 percent over a nine-year period, compared to 4.07 percent for the relevant group in high capital market countries. This difference between high and low capital market development countries may indicate the possibility of more growth opportunities for efficient affiliates in low financial-market development countries, because local firms may be less competitive than local firms in high stock market capitalization countries.

\section{B. Growth of U.S. MNCs: Firm-Specific Resources}

Table IV presents our base specification and estimates it for the full sample and for the sample split by the size of the MNCs network of affiliates in the prior year. Our main tests in Table IV examine the predictions of Hypotheses 1. First, we predict a positive association between affiliate i's growth and its relative efficiency*GDP growth. Second, we predict that if firm-specific resources of the MNC face decreasing returns-to-scale, affiliate growth should be negatively related to the MNC's other affiliates' efficiency*relative demand growth. If trade-offs exist relative to the parent, we expect the coefficient on the interaction of the parent's efficiency*relative demand growth to be negative.

\section{Insert Table IV - Growth of MNC Affiliates}

The results in column 1 in Table IV show that, consistent with Hypothesis 1, more efficient affiliates grow more in response to demand growth. This result is indicated by the significant coefficient on the Relative Efficiency (MNC-industry-year)*GDP growth interaction.

We also find a strong positive association between affiliate growth and the absolute efficiency of other affiliates within the MNC. Not only do more efficient affiliates grow significantly more, but affiliates from MNCs with more efficient networks of affiliates and more 
efficient U.S. parents also have significantly higher growth. From these results, it appears that there is a skill to operating foreign affiliates that is associated with higher growth, both globally and in the home country.

When we examine the interaction variables, we find evidence of trade-offs within the MNC, as postulated in part (ii) of Hypothesis 1. We find a significant negative coefficient on the other affiliates' efficiency interacted with their relative demand growth. This negative coefficient could indicate that there are trade-offs to growth within the MNC as well as scarce resources with decreasing returns-to-scale.

We note that we are testing for a differential slope for the response to demand changes based on relative within-MNC efficiency. Thus, the significant negative coefficient shows that affiliates grow less (from a base level of growth given by the control variables) if other affiliates are efficient and receive a positive demand shock. This finding is consistent with intra-MNC trade-offs to growth.

In columns 2 and 3 we test the predictions of Hypothesis 2 by splitting the sample by the R\&D-to-sales ratio of the MNC parent. For affiliates of low-R\&D parents, we find a significant interaction effect between other affiliates' efficiency and their relative demand growth. This finding is consistent with there being trade-offs to growth among those affiliates of MNCs that do not compete on the basis of greater knowledge assets. Surprisingly, the results in column 3 show that affiliates of high-R\&D MNCs may compete for resources with their parents. This finding shows in the significant negative coefficient on parent efficiency*relative demand growth. This result is surprising if we view R\&D as a resource that has constant or increasing returns to scale. This result is examined further in Table V.

Table V examines the R\&D results by the size of the MNC's network. Table V uses the previous R\&D classifications and splits these subsamples at the median MNC network size in the prior year.

\section{Insert Table V - Effect of Size and R\&D}

Columns 1 and 2 in Table $\mathrm{V}$ show that there are trade-offs with other affiliates within the MNC network in both high and low R\&D MNCs with small networks. The interaction variable, other affiliate efficiency*relative GDP growth, is strongly significant and negative. These results show that within-MNC trade-offs are concentrated in the MNCs with small 
networks of affiliates, regardless of R\&D. This result indicates that an affiliate of a small network MNC grows less when other efficient affiliates within the same network have high relative demand growth. This finding gives evidence of scarce resources with decreasing returns-to-scale within the MNC. We also find evidence of a very strong positive association between affiliate growth and affiliate efficiency*GDP growth. Regardless of MNC R\&D, efficient affiliates from MNCs with small networks are highly responsive to demand growth, perhaps because they can get more resources to grow if they have strong demand and are efficient enough to respond to it.

Consistent with the part ( $i i)$ of Hypothesis 2, there is evidence of within-MNC tradeoffs in high R\&D MNCs with small networks as shown in column 2. The focal affiliate in these MNCs appears to compete with both the parent and other affiliates for scarce resources. These results show that the trade-off we find in Table IV between affiliate growth and parent efficiency*relative demand growth exists only in MNCs with small networks. Affiliates of high-R\&D MNCs with large networks show no intra-firm trade-offs to growth.

We also find a strong positive effect of affiliate $i$ 's efficiency for MNCs with high R\&D and small affiliate networks, especially efficiency relative to other affiliates within the MNC. These results support $R \& D$ as being a scarce resource with a high value that the MNC allocates to the most efficient affiliates when the MNC network is small and the MNC has high R\&D. Perhaps similar to Himmelberg and Petersen's (1994) results for small, high-R\&D firms in the U.S., it may be the case that small MNCs lack the financial and organizational resources necessary to exploit their $R \& D$ throughout a global network. The fact that we find no trade-offs to growth among the affiliates of high-R\&D MNCs with large networks gives some evidence that if the affiliates attain a certain size, MNCs can transfer R\&D throughout their networks with constant returns to scale.

\section{Access to Financing as a Scarce Resource}

In Table VI, we test Hypothesis 3 on the importance of access to financial capital as an $\mathrm{MNC}$ resource. We propose that affiliates with less access to financing may face more competition for resources with other affiliates in the MNC network. We split the previous size-based samples at the median of affiliate financing. Since current period financing may be correlated with affiliate productivity and opportunities, we spilt the sample based on affiliates' prior-year financing and include efficiency variables. 


\section{Insert Table VI - Affiliate Financing}

The results in the first column of Table VI support part ( $i i)$ of Hypothesis 3, that there are more within-MNC trade-offs to growth for affiliates with less financing within small network MNCs. The coefficient on other affiliate efficiency*relative demand growth is highly significant and negative. This result supports the conclusion that affiliates with less financing compete more for resources with other affiliates of the MNC.

Table VIb presents the economic significance of the regression results from Table VI. First, for each of the regressions in columns one to four, we vary from the tenth to the 90th percentile the affiliate's own efficiency and the interaction of affiliate efficiency*demand growth, while holding all other variables constant at their respective sample medians. Second, we vary from the tenth to the 90th percentile the MNC's other affiliates' and parent's efficiency and the interaction of these efficiency variables with parent and other affiliate relative demand growth, again holding all other variables at their respective sample medians.

We find that the regression results for the trade-off variables have both economically important differences and statistical significance. In the bottom panel of Table VIb we examine the economic significance of the MNC parent and other affiliates' efficiency on affiliate employment growth for MNCs with large and small affiliate networks with high and low financing. We find that for affiliates from small MNC networks with low financing, as we go to the 90th percentile of other affiliates' and MNC parent's efficiency, growth is reduced from 0.84 percent to -0.76 percent, a range of 1.6 percentage points per year. In contrast, the last two rows of Table VIb show that in MNCs with large networks, the effect of other affiliates' and MNC parent's efficiency on affiliate growth is relatively small, regardless of the affiliates' use of financing. As we go from the tenth to the 90th percentiles of other affiliate and parent efficiency*relative demand growth, we see that the growth of affiliates of MNCs with large networks varies slightly less than 0.2 percentage points for those with low use

of parent and local financing and only 0.32 percentage points for those with higher use of parent and local financing. Thus, we find that the economic importance of trade-offs within the MNC is greater for MNCs with small affiliate networks. 


\section{Market-Specific Factors: Financial Markets and Institutions}

In Hypothesis 4, we extend our findings on affiliate financing by examining two related issues. First, we ask if affiliate growth increases with parent financing in countries with less developed capital markets. We examine both stock and bank credit measures of capital market development. ${ }^{11}$ Since MNC affiliates can borrow from their U.S. parents for operations in countries where local financing may be limited, we could expect that affiliates with greater access to capital from within the MNC will grow more. However, we also predict in Hypothesis 4 that greater parent financing may be associated with increased trade-offs to growth within the MNC, because parent financing may be withdrawn if growth opportunities elsewhere within the MNC improve. If organizational size is important to an MNC's ability to obtain financing, we also expect parent financing to be associated with greater intra-firm trade-offs to growth for affiliates of MNCs with small networks.

Because we predict affiliates can more easily substitute local for parent financing in countries with developed capital markets, our predictions in Hypothesis 4 focus on affiliate growth in low-stock market capitalization countries. ${ }^{12}$

\section{Insert Table VII - Source of Financing and Financial Market Development}

We test Hypothesis 4 in two steps. First, we create a variable that measures the percentage of financing obtained from the focal affiliate's U.S. parent. A priori, we predicted that since internal MNC financing could be withdrawn from the focal affiliate for opportunities elsewhere within the MNC, there should be greater within MNC trade-offs to growth for affiliates with greater parent financing. However, the degree to which the MNC might take advantage of these opportunities should depend on whether it has efficient affiliates (or U.S. operations) and large relative demand growth in the respective locations. Therefore, we create a three-way interaction variable: percentage parent financing*other affiliate (U.S. parent) efficiency*other affiliate (U.S. parent) relative demand growth. We estimate the regressions in separately, because the two three-way interactions are too collinear to estimate in one equation. The interaction of percentage parent financing*other affiliate efficiency*other

\footnotetext{
${ }^{11}$ The results using the measure of bank credit availability (claims on the private sector by deposit money banks divided by GDP) are similar thus we just report and discuss those based on stock market capitalization.

${ }^{12}$ The results of these specifications for the high stock market capitalization countries are available from the authors (as are other specifications which are discussed, but not presented here).
} 
affiliate relative demand growth is insignificant for both large and small MNC networks. Consequently, we show only the results for the specifications that include the interaction of percentage parent financing* parent efficiency* parent relative demand growth. Evidently, the growth of affiliates that receive more parent financing in less developed financial markets is affected more when there are growth opportunities in the U.S. market than in other foreign markets.

We find that, contrary to our expectations as postulated in part ( $i$ ) of Hypothesis 4, affiliate growth does not increase with parent financing in countries with less developed financial markets. The coefficient on percentage parent debt financing, although not significant, actually has a negative sign for affiliates from large MNC networks. The sign is positive, but the coefficient is still not significant, for affiliates from small MNC networks.

We find, perhaps surprisingly, that in low stock market capitalization countries, there are significant within-MNC trade-offs to growth between affiliates and their U.S. parents. This result holds for affiliates of MNCs with small and large networks. It may be the case that growth in low stock market capitalization countries is sufficiently intense in "headquarters services" (Helpman, 1984) to show some decreasing returns to scale.

However, there is an interesting difference in the trade-offs in the large and small MNC network subsamples. For affiliates of MNCs with large networks, U.S. parent efficiency*relative demand growth is negatively associated with the growth of the focal affiliate. However, the trade-off appears to be unrelated to the extent to which the focal affiliate obtains financing from its parent.

In contrast, for affiliates from MNCs with small networks, the negative trade-offs with U.S. parents depend on the percentage of financing the affiliates receive from parents. The three-way interaction variable (efficiency of U.S. parent interacted with parent relative demand growth and the percentage financing from the parent) is significant and negative for small network affiliates in low stock market capitalization countries. This result is consistent with the parts $(i i)$ and (iii) of Hypothesis 4.

Our findings thus suggest that when MNCs grow in low stock market capitalization countries, both the financial and organizational resources from the parent are critical to growth. MNCs with small networks appear to be particularly lacking the internal financial resources to grow without trade-offs in low stock market capitalization countries. In contrast, 
MNCs with large networks appear to face decreasing returns to organizational resources when growing in these markets.

In Table VIII we test the importance of host country contracting effectiveness, as discussed in Hypothesis 5. We predict that better host country contracting effectiveness, particularly in low stock market capitalization countries, will benefit those MNC affiliates that transact more with local firms, because better host-country institutions should facilitate trade between local firms and MNC affiliates. We expect little or no effect of better hostcountry contracting effectiveness on the growth of affiliates that conduct more transactions within the MNC.

To test this hypothesis, we split the countries into two groups based on stock market capitalization/GDP (as in the previous table), and we include in the specification the annual measure of a country's contracting effectiveness obtained from IRIS.

\section{Insert Table VIII - Contracting Effectiveness}

Our results in column 1 show that greater contracting effectiveness within the low stock market capitalization countries has a positive effect on MNC affiliate growth. Improved contracting effectiveness is not associated with affiliate growth in high stock market capitalization countries, as shown in column 4.

We then split the sample of affiliates into quartiles based on intra-MNC trade in the low market capitalization subsample. Since most affiliates trade very little within the MNC (the median is close to zero), we use the 75th percentile to split affiliates into high intraMNC trade and low trade. Firms at the 75 th percentile conduct approximately 25 percent of trade within the MNC. Consistent with Hypothesis 5, we find that the positive result for contracting effectiveness appears only for affiliates that conduct most of their transactions with local firms. In addition, as shown in column 3, the negative coefficient on the interaction of U.S. parent efficiency*relative GDP growth implies that trade-offs within the MNC in low stock-market capitalization countries are significant only for affiliates that trade extensively within the MNC.

Thus, it appears that MNCs that internalize more transactions may be relatively protected from weak domestic institutions. However, when domestic institutions improve, these affiliates do not grow as much as affiliates that trade more with local firms - a result complementary to La Porta, Lopez-de-Silanes, Shleifer and Vishny's (1997) finding that domestic 
firms in countries with stronger institutions have the ability to grow more. This result also appears to be the case for MNC affiliates, but only for those affiliates that transact more with local firms.

\section{E. Dynamic Effects: The Effect of an Increase in Stock Market Development}

We further expand our analysis by considering the effects of changes in capital market development over time. We examine the proposition (related to Hypothesis 4) that as capital markets develop, MNC affiliates will face fewer within-firm trade-offs as they should find it easier to raise capital locally. Given that local borrowing is an important source of affiliate financing, development of local capital markets should enable affiliates to grow more in response to demand growth. Local firms will also be able to trade more with MNC affiliates when capital markets develop. Conversely, it may be the case that MNC affiliates will grow less in response to demand growth as capital markets develop, because competition from local firms intensifies.

To explore these ideas, we examine affiliate growth in countries that have had very high stock market growth over the sample window from 1983-1985 to 1994-1996. We do so by using the median stock market-capitalization- to-GDP growth over a three-year period for beginning and ending values. We examine all affiliates in the upper quartile of stock market growth. We then split this sample of affiliates into two periods, an early period from 19831989 and a late period from 1990-1996. Table IX presents the regression results for these two time periods.

\section{Insert Table IX - Increases in Stock Market Development}

We find several interesting results in Table IX. First, efficient MNC affiliates grow more in response to positive demand changes in the later period, as is evident in the significant positive coefficient on the affiliate's relative efficiency*GDP growth. Second, as shown by the significant negative coefficient on U.S. parent efficiency*GDP growth in the early period and insignificant coefficient in the later period, affiliates face lower within-MNC trade-offs to growth as local capital markets develop. These findings support the proposition that MNC affiliates are able to do more business with local firms and to raise more capital locally as financial markets develop. The reduced trade-off to growth in relation to U.S. parents in the later period extends our earlier results in which we find that affiliates in low stock 
market capitalization countries appear to compete for resources with their U.S. parents. It may be the case that growing an affiliate in these markets requires considerable financial and organizational resources, particularly from U.S. headquarters, that become less critical as local markets develop.

Table IXb presents the economic significance of the regression results from Table IX. First, holding all other variables constant at their respective sample medians for the regressions in Table IX, we vary the affiliate's own efficiency and the interaction of affiliate efficiency*GDP growth from the tenth to the 90th percentile. Second, we vary from the tenth to the 90th percentile the MNCs' other affiliates' and the MNC parents' efficiency and the interaction of these efficiency variables with parent and other affiliates' relative demand growth, again holding constant all other variables at their respective sample medians.

We find that the regression results have economic importance in addition to statistical significance. Table IXb shows that higher affiliate efficiency is associated with considerably higher affiliate employment growth. Affiliate growth increases from -4.38 percent to 2.3 percent, an increase of 6.68 percentage points per year, as efficiency and demand increase from the tenth to the 90th percentile for MNCs in the later period.

When we examine the economic significance of the parent and other affiliates' efficiency on affiliate growth in the two periods, we find that the economic importance of the tradeoffs within the MNC exist primarily in the first period in countries with large increases in stock-market development. In the first period, affiliate growth is reduced from 1.77 percent to 0.56 percent as we go from the tenth to the 90th percentile of other-affiliate and MNC parent efficiency. Again, these results support the notion that organizational resources are necessary to grow MNC affiliates in developing economies.

The last row of Table Xb shows that the effect of the parent and other affiliates' efficiency on affiliate growth in the later period is relatively small, and becomes positive as we go from the tenth to the 90 th percentile. Thus, we find that the economic importance of trade-offs within the MNC is higher for MNC affiliates when local capital markets are less developed.

\section{F. Robustness of our Results}

We check to see if our results are robust to alternate measures of affiliate growth and affiliate efficiency. We examine whether the growth in real affiliate assets responds to the same efficiency and trade-off variables as the growth in employment. Overall, we find similar 
results, despite affiliate assets potentially suffering from country differences in accounting rules and exchange rate movements. These differences may be mitigated to the extent foreign affiliates of U.S. MNCs follow U.S. accounting procedures (as is required by the BEA). We do find stronger significance for the change in exchange rates in these regressions. This finding is perhaps not surprising, given that assets are translated back into U.S. dollars at end-of-year exchange rates. Using employment growth avoids this problem. As we discuss in the data appendix, we also explore several alternative measures of affiliate efficiency, using simpler cash flow based measures of efficiency, and find similar results.

Second, we examine the possible effect of measurement error in the efficiency and relative GDP growth variables. We wish to be sure that there is no systematic bias in efficiency measures when there are either very few or very many affiliates within the MNC. In the former case, our main concern is that there would be no "comparison" affiliates within the $\mathrm{MNC}$ in the same industry-year as the focal affiliate. In the latter case, our concern is that by pooling either efficiency or demand growth across multiple affiliates - some of which had positive efficiency (or demand growth) and some of which had negative efficiency (or demand growth)-we would create "noisy" measures of efficiency and/or demand growth.

On the first issue of too few affiliates, fewer than one tenth of one percent of MNCs in our sample do not have multiple affiliates in the same industry, and our results are robust to the exclusion of these firms. Moreover, the median number of affiliates in the same industry for MNCs in the "small network" subsample is five. ${ }^{13}$

For both demand growth and efficiency measures in MNCs with many affiliates, we also examine discrete variables $(-1,0,1)$ that indicate whether the other affiliates' efficiency is lower, equal to, or greater than, the affiliate in question. We also use only the largest other affiliate's efficiency as a measure of alternative opportunities available to the MNC. In both cases we obtain similar results to those reported here.

Third, we explore the robustness of our results to possible alternative explanations. We consider the fact that the observed "trade-offs" within MNCs might be optimizing behavior, in the sense that MNCs can shift production in and out of different countries as cost or

\footnotetext{
${ }^{13}$ To some extent, this is because smaller MNCs are more likely to have estimated data, and we removed all estimated observations from our sample. However, we still have a wide range in the number of affiliates per MNC. Specifically, since we use only reported data, and all our affiliate and MNC variables are lagged, we are conditioning on an affiliate appearing at least twice consecutively, with no estimated data.
} 
demand conditions change throughout the global network of affiliates. If our results are picking up "optimizing" production shifts, we would expect to find the following patterns. First, there should be considerably less shifting of production among diversified MNCs, as these are less likely to have plants in different countries that can easily manufacture the same products. Second, we should find more production shifting in larger MNCs, as these are more likely to have multiple plants that can produce the same things. We should also observe considerably more production shifting among MNCs that trade extensively intrafirm, as these MNCs have established the mechanisms to shift production and transfer the output from different plants throughout the network.

To explore these ideas, we create measures of both MNC intra-firm trade and diversification. (The diversification measure is based the BEA's 2-3 digit industry codes, which correspond primarily to three-digit SIC codes, with some two-digit level codes.).

We run the basic specification from Table IV and split affiliates into high and low categories of intra-MNC trade and also into high and low categories based on parent diversification. The benefit of using actual intra-MNC trade is that this measure can directly capture whether firms are truly diversified and potentially have no product-market connections between MNC divisions. Using SIC codes or other industry classification codes will not capture vertical integration or other forms of trade within firms.

We examine whether less diversified MNCs (and MNCs that operate in related industries) face larger or smaller trade-offs within the network. We find more significant trade-offs in MNCs that operate in more related industries and trade more intra-firm. This result appears to be consistent with "optimizing" production shifting.

However, when we examine the high and low intra-MNC trade and diversification samples by the size of the MNC network, we find that MNC size has an important influence on the effects of relatedness. We find significant within-MNC trade-offs for affiliates of small MNC networks with highly diversified parents. This finding is opposite to the expected pattern under the production-shifting scenario. We also find no significant trade-offs for affiliates of large-network MNCs, regardless of the MNCs' level of intra-firm trade.

Another possible explanation is that the trade-offs we find may be driven by diversified firms misallocating resources - although the results suggest that efficient affiliates in countries with positive changes in demand receive more, not less resources. However, our results are 
unaffected by product-line diversification, measured by either industry codes or by identifying MNCs that do not trade much within the firm. We find no trade-offs for affiliates of highly diversified MNCs with large affiliate networks.

Thus, we conclude that our results support the existence of trade-offs to growth within the MNC that stem primarily from resource constraints, and that our results are robust to the extent of intra-MNC trade and diversification.

\section{Conclusions}

In this paper, we examine MNC growth across networks of affiliates. We examine how changes in local demand and demand in the MNC's other markets affect MNC affiliate growth. Our results for MNC growth, affiliate financing patterns, and financial-market development provide evidence on the kind of resources that create advantages for MNCs. Our tests indicate whether firm-specific resources face decreasing returns to scale - and thus cause trade-offs to growth - in their application within the MNC.

We examine the importance of MNC R\&D, organizational resources, and access to financing. Our primary findings on these firm-specific resources are:

1. Small, high-R\&D MNCs face significant trade-offs to growth within the MNC.

2. Trade-offs within MNCs with small affiliate networks are particularly important when affiliates have less combined host-country and parent financing.

3. MNCs with large affiliate networks face few intra-firm trade-offs to growth.

These results provide evidence that organizational and financial resources are important to an MNC's ability to exploit knowledge assets created through R\&D. Our findings are consistent with large-network MNCs possessing organizational and financial capital that are in scarce supply for MNCs with smaller affiliate networks. MNCs with large affiliate networks seem to face few intra-MNC trade-offs to growth.

Relating our results to Helpman's (1984) theory of the MNC, given we find no tradeoffs to growth in high-R\&D MNCs with large affiliate networks, it may be the case that knowledge assets and "headquarters services" face constant returns to scale. However, it 
seems to be the case that to achieve growth without trade-offs across affiliate networks, an MNC must possess significant organizational and financial resources.

Our second major set of results shows that country financial market development and institutional development affect affiliate growth and within-MNC trade-offs. Our findings on the importance of host-country financial and institutional development are:

1. In countries with less-developed financial markets, our evidence is consistent with affiliates competing for resources with their U.S. parents. These parent-affiliate trade-offs are particularly acute for MNCs with small networks and greater affiliate reliance on parent financing.

2. In countries with less-developed financial markets, MNC affiliates benefit from improvements in host-country contracting effectiveness. This result is particularly significant for those affiliates that trade extensively with local firms.

3. In countries with rapidly developing financial markets, intra-MNC trade-offs diminish and affiliate growth becomes more sensitive to own-efficiency and local market demand over time.

These results are consistent with the proposition that MNC affiliates benefit from access to more local financing and the ability to trade more with domestic firms. MNC affiliates that conduct more transactions within the firm are relatively sheltered from host-country institutions, with no significant benefits found from improvements in institutions. MNC affiliates that operate in countries with well-developed capital markets have smaller withinMNC trade-offs and are not affected by changes in host-country contracting effectiveness.

Overall, our evidence is consistent with access to financing and organizational capital being important resources for MNC growth. Our results also provide support for the proposition that stronger host-country institutions and financial-market development benefit MNCs. 


\section{REFERENCES}

Allen, Franklin and Douglas Gale, 2000, Financial contagion, Journal of Political Economy 108(1) 1-33.

Baldwin, Richard E., 1988, Hysteresis in import prices: The beachhead effect, American Economic Review 78(4): 773-78.

Bodnar, Gordon M., Charles Tang, and Joseph Weintrop, 1999, Both sides of corporate diversification: The value impacts of global and industrial diversification, Working paper, Johns Hopkins University.

Buckley, Peter and Marc Casson, 1976, The Future of the MNC. New York: Holmes \& Meier.

Caves, Richard E., 1982, Multinational Enterprise and Economic Analysis. London: Cambridge University Press.

Clague, Christopher, Philip Keefer, Stephen Knack and Mancur Olson, 1996, Property and contract rights under democracy and dictatorship, Journal of Economic Growth 1, 243-276.

Coase, Ronald, 1937, The nature of the firm, Economica 4: 386-405.

Demirgüç-Kunt, Asli, and Vojislav Maksimovic, 1998, Law, finance, and firm growth, Journal of Finance 53: 2107-2137.

Denis, David J., Diane K. Denis and Keven Yost, 2002, Global Diversification, Industrial Diversification, and Firm Value, forthcoming Journal of Finance.

Desai, Mihir, 1999, The Substitutability of Foreign and Domestic Capital: Evidence from TRA, Mimeo, Harvard University.

Dixit, Avinash, 1989, Hysteresis, import penetration, and exchange-rate pass-through, Quarterly Journal of Economics 2: 205-228.

Dunning, John, 1973, The determinants of international production, Oxford Economic Papers 25: 289-336.

Errunza, Vihang R. and Lemma W. Senbet, 1981, The effects of international operations on the market value of the firm: Theory and Evidence, Journal of Finance 36: 401-417.

Errunza, Vihang R. and Lemma W. Senbet, 1984, International corporate diversification, market valuation, and size-adjusted evidence, Journal of Finance 39: 727-743. 
Fazzari, Stephen M., R. Glen Hubbard, and Bruce C. Peterson, 1988, Financing constraints and corporate investment, Brookings Papers on Economic Activity, 145-195.

Feinberg, Susan E. and Michael P. Keane, 2001, U.S. Canada trade liberalization and MNC production location, The Review of Economics and Statistics 83(1): 118-132.

Helpman, Elhanan, 1984, A simple theory of international trade with multinational corporations, Journal of Political Economy 92: 451-471.

Himmelberg Charles P. and Bruce C. Petersen (1994) R\&D and Internal Finance: A Panel Study of Small Firms in High Tech Industries, Review of Economics and Statistics $76(1): 38-51$.

Kim, Wi Saeng and Esmeralda O. Lyn, 1986, Excess market value, the multinational corporation, and Tobin's q ratio, Journal of International Business Studies 17: 119-126.

King, Robert, and Ross Levine, 1993, Finance and growth: Schumpeter might be right, Quarterly Journal of Economics 108(3), pp. 717-37.

Lamont, Owen, 1997, Cash Flow and Investment: Evidence from Internal Capital Markets, Journal of Finance 52, 83-109.

LaPorta, Rafael, Florencio Lopez de-Silanes, Andrei Shleifer and Robert W. Vishny, 1997, Legal determinants of external finance, Journal of Finance 52, 1131-1150.

Levine, Ross, 1997, Financial Development and Economic Growth: Views and Agenda, Journal of Economic Literature 35(2): 688-726.

Lombardo, Davide, 2001, Is there a cost to poor institutions?, Mimeo, Stanford University.

Lucas, Robert, 1978, On the size distribution of firms, Bell Journal of Economics 9: 508523.

Maksimovic, Vojislav and Gordon Phillips, 2002, Do conglomerate firms allocate resources inefficiently across industries? Theory and Evidence, Journal of Finance 57, 721-67.

Mataloni, Raymond J. and Lee Goldberg, 1994, Gross product of U.S. multinational companies, Survey of Current Business 72(2): February.

Morck, Randel and Bernard Yeung, 1991, Why investors value multinationality, Journal of Business April: 165-188.

Moulton, Brent, 1986, Random group effects and the precision of regression estimates, Journal of Econometrics 32, pp. 385-397. 
OECD, 1999, Measuring Globalization: The Role of Multinationals in OECD Economies. Paris, France: OECD.

Rajan, Raghuram G. and Luigi Zingales, 1998, Financial dependence and growth, American Economic Review 559-586.

Rugman, Alan, 1981, Inside the Multinationals: The Economics of Internal Markets. London: Croom Helm.

Scharfstein, David S., 1998, The Dark Side of Internal Capital Markets II: Evidence from Diversified Conglomerates, NBER working paper 6352.

Scharfstein, David S., and Jeremy C. Stein, 2000, The dark side of internal capital Markets: divisional rent-seeking and inefficient investment, Journal of Finance 55, 2537-2564.

Shin, H. and Rene Stulz, 1998, Are Internal Capital Markets Efficient? Quarterly Journal of Economics, v113, 531-52.

Turner, Anthony and Stephen Golub, 1997, Towards a system of multilateral unit labor costbased competitiveness indicators for advanced, developing and transition economies, International Monetary Fund, working paper 97-151.

Vernon, Raymond, 1971, Sovereignty at Bay: The Multinational Spread of U.S. Enterprises. New York: Basic Books.

Wheeler, David and Ashoka Mody, 1992, International investment location decisions: The case of U.S. Firms, Journal of International Economics 33: 57-76.

Williamson, Oliver E., 1975, Markets and Hierarchies. New York: Free Press.

Wurgler, Jeffrey, 2000, Financial markets and the allocation of capital, Journal of Financial Economics 58, 187-214. 


\section{Data Appendix}

This appendix contains the details on how we constructed the sample used in our study and how we measured affiliate efficiency.

We used the BEA data over the 14-year window from 1983-1996. We made several alterations to the BEA population to construct the panel used in this research. First, because the BEA conducts two different surveys (the Benchmark and Annual Surveys) with different reporting requirements in terms of affiliate size, reported data were not available for all the affiliates throughout the 14-year period. The Benchmark Surveys, conducted in 1977, 1982, and again in 1989 and 1994, included the whole population of MNCs and their foreign affiliates, and smaller affiliates were required to report data. But in the Annual Surveys, many of the small affiliates that reported data in the 1989 and 1994 Benchmark Surveys were exempt from filing. In cases in which affiliates reported data in a Benchmark Survey but were exempt from the Annual Surveys, the BEA carried them forward by estimating data. $^{14}$

As a result of this sampling procedure, many of the observations for smaller affiliates were estimated for most of the 14-year period. In an initial screen, we removed all estimated data from our sample. (See Feinberg and Keane, 2001, for a detailed discussion of the BEA panel.) After this screen, our panel contained approximately 155,000 affiliate-year observations out of a population of 256,000 .

In our second screen, we kept only affiliates in countries for which we had real exchange rate data. Approximately 18,800 observations were dropped in this screen, but our remaining sample of 137,000 affiliate-year observations accounted for 95 percent of total affiliate sales (among affiliates that reported data). In other words, the number of affiliates that reported data in countries dropped from our sample in this step was relatively small. For the regressions reported, we also excluded data for which we were not able to calculate affiliate efficiency, as described later in this section. We did calculate efficiency for approximately 109,600 affiliate-year observations. For these affiliate observations, we were able to calculate a measure of parent efficiency for 92,200 affiliate-year observations.

Because we specified our dependent variable (affiliate employment growth) as a change,

\footnotetext{
${ }^{14}$ These individual affiliates which are carried forward are small and are thus are not likely to have a significant impact on the BEA's published data at the industry or country level.
} 
and because we used lagged independent variables, we removed affiliates with missing data and/or non-consecutive observations from our sample. This screen resulted in the removal of a large number of affiliate-year observations, because many affiliates only had only one or two non-consecutive reported data points (typically, one for each Benchmark year, 1989 and 1994).

We also excluded affiliates in which the parent had only a partial ownership stake. This criterion affected only 3,620 affiliate-year observations and did not change significantly any of our reported results.

Finally, we excluded the bottom and top one percent of observations for each of the growth and efficiency variables. Given the high correlation in outliers across these variables based on this outlier screen, we excluded approximately three percent of the data. Our final regression sample includes 34,384 affiliate-year observations on 8,106 affiliates of 862 U.S. parents producing in 41 countries.

We measured affiliate efficiency as [(Real affiliate gross product)/affiliate employment] at time $(t-1)$, where gross product was an economic accounting measure of an affiliate's valueadded constructed by the BEA (see Mataloni and Goldberg, 1994). This measure of gross product is the sum of local affiliate costs plus affiliate profits in production. The advantage of this measure over a cash-flow accounting measure is that it is not as subject to potential accounting allocation of non-production and overhead costs across countries by the parent. We deflated this measure by industry-level price deflators to get a real dollar measure and then divided by affiliate employment. We used this basic measure of efficiency to calculate three measures of affiliate efficiency, two relative efficiency measures for affiliate $i$, and an efficiency measure for the other affiliates in affiliate $i$ 's network.

For robustness, we also explored several alternative measures of affiliate efficiency in addition to the ones discussed here. (We do not report results using the other measures, but they are available on request.) The alternative measures showed no systematic differences from the measure we use here. The other measures were closer to cash flow measures of efficiency [(affiliate sales - cost of goods sold)/affiliate employment] and [(affiliate sales employee compensation)/affiliate employment]. Both these measures were also divided by sales, rather than employment, as the third and fourth measures.

Our first measure of affiliate efficiency was within-MNC (industry and year adjusted) 
efficiency. Because we predicted that MNCs will allocate resources to affiliates with a comparative advantage within the MNC, this variable measures affiliate $i$ 's efficiency in a given year relative to other affiliates in the same MNC in the same industry as affiliate $i$. We calculated affiliate $i$ 's within-MNC efficiency by subtracting from affiliate $i$ 's efficiency the average efficiency of other same-industry affiliates of the same parent as affiliate $i$. We expected that affiliates that were relatively more efficient within the MNC would have higher growth. We note that in addition to predicting absolutely higher growth for affiliates with higher within-MNC efficiency, our hypotheses predicted that MNCs will allocate resources to affiliates that were relatively more efficient and have positive changes in demand. Accordingly, we calculated an interaction between affiliate $i$ 's within-MNC efficiency and its demand change.

Our second measure of affiliate efficiency is the efficiency of affiliate $i$ relative to other MNC affiliates in the same industry in the same country-year. We constructed this measure by subtracting from affiliate $i$ 's efficiency the average efficiency of unrelated MNC affiliates in the same country, year, and industry as affiliate $i$. We expected that MNCs would allocate more resources to affiliates which were relatively efficient (compared with other same-industry affiliates) within a given host country.

The third measure of affiliate efficiency is a weighted average of the efficiency of all the affiliates of a given MNC parent (excluding affiliate $i$ ). To construct this measure, we summed together (efficiency*sales) for all affiliates (other than affiliate $i$ ) of a given parent, $p$, and divided by the total sales of all the affiliates of parent $p$ (other than affiliate $i$ ). Our main predictions for other affiliate efficiency center around the interaction between other affiliate efficiency and the other affiliates' demand changes.

Our final measure of efficiency is for the U.S. parent. We measured parent $p$ 's efficiency by (sales - employee compensation)/employment (at time $(t-1)),{ }^{15}$ and we industry- and year- adjusted this measure by subtracting from parent $p$ 's efficiency the mean efficiency of all U.S. parents in the same industry-year. Again, our main prediction for this variable focuses on the interaction between parent $p$ 's efficiency and its relative change in demand.

\footnotetext{
${ }^{15}$ We use this measure of parent efficiency rather than real gross product because we do not have a full series of gross product data for U.S. parents. We do not expect this should bias our results for parent efficiency given that similar measures of affiliate efficiency used in earlier specifications yielded the same results as the gross product-based measures.
} 
Table I

Sample Characteristics of U.S. MNC Foreign Affiliates, 1983-1996

Productivity variables are industry- and year-adjusted. Affiliate efficiency is a labor value-added measure and is calculated as real affiliate gross product divided by affiliate employment. We calculate parent efficiency as sales less cost of goods sold divided by parent employment. Percentages of total debt from the parent and local sources do not add up to $100 \%$, because firms can borrow from other countries and from other sources in the U.S. We convert all sales and cost data into 1982 dollars using BLS three-digit industry deflators. We obtain capital market development data from the IFC. Quartiles are determined by ranking countries by their stock market capitalization each year. High and low R\&D groups are based on the median parent R\&D for each year. Multinational affiliate data are from the Bureau of Economic Analysis.

\begin{tabular}{|c|c|c|c|}
\hline & \multicolumn{3}{|c|}{ Sample of Firms } \\
\hline & $\underline{\text { All Affiliates }}$ & $\begin{array}{l}\text { Affiliates of } \\
\text { MNCs with } \\
\text { Low R\&D }\end{array}$ & $\begin{array}{l}\text { Affiliates of } \\
\text { MNCs with } \\
\text { High R\&D }\end{array}$ \\
\hline \multicolumn{4}{|l|}{ Panel A: Affiliate Characteristics } \\
\hline Affiliate size (median, $1982 \$ 000$ ) & 35,018 & 27,973 & 37,016 \\
\hline MNC parent size (median, $1982 \$ 000)$ & $2,142,239$ & $3,095,396$ & $1,999,663$ \\
\hline Number of affiliates & 8,106 & 2,173 & $6,014^{\mathrm{d}}$ \\
\hline $\begin{array}{l}\text { Efficiency of affiliate (median) } \\
\text { relative MNC-industry-year }\end{array}$ & 0.0 & 0.0 & 0.0 \\
\hline $\begin{array}{l}\text { Efficiency of affiliate (median) } \\
\text { relative country-industry-year }\end{array}$ & 0.0 & 0.0 & -0.6 \\
\hline \multicolumn{4}{|l|}{ For highest efficiency (above 50th percentile) affiliates } \\
\hline Average affiliate employee growth rate & $0.6 \%$ & $0.2 \%$ & $0.7 \%$ \\
\hline Average MNC parent growth rate & $2.7 \%$ & $2.6 \%$ & $2.8 \%$ \\
\hline Average efficiency of MNC parent & 21.9 & 42.8 & $14.8^{\mathrm{a}}$ \\
\hline Average efficiency of other affiliates in network & 4.1 & 2.5 & $4.6^{\mathrm{a}}$ \\
\hline R\&D to sales ratio of MNC parent (average) & $5.5 \%$ & $2.4 \%$ & $6.4 \%{ }^{\mathrm{a}}$ \\
\hline Debt to asset ratio for affiliates (average) & $53.8 \%$ & $57.7 \%$ & $52.3 \%^{\mathrm{a}}$ \\
\hline$\%$ debt from parent (average) & $16.5 \%$ & $13.5 \%$ & $17.4 \%{ }^{a}$ \\
\hline$\%$ debt from local borrowing (average) & $65.2 \%$ & $68.3 \%$ & $64.3 \%{ }^{a}$ \\
\hline$\%$ affiliate sales within MNC (average) & $19.5 \%$ & $15.7 \%$ & $26.0 \%{ }^{\mathrm{a}}$ \\
\hline \multirow[t]{3}{*}{$\%$ Sales in local country (Average, outside MNC) } & $78.5 \%$ & $85.3 \%$ & $76.4 \%{ }^{a}$ \\
\hline & \multicolumn{3}{|c|}{ Countries with the } \\
\hline & & Lowest & Highest \\
\hline Panel B: Country Characteristics & All Countries & Stock Market & italization / GDP \\
\hline Average change in real GDP (1 year) & $3.76 \%$ & $3.31 \%$ & $4.17 \%$ \\
\hline Average change in real GDP ( 5 year) & $14.36 \%$ & $12.96 \%$ & $15.70 \%$ \\
\hline Average stock market capitalization / GDP & 0.431 & 0.130 & 0.712 \\
\hline Number of MNC affiliates & 8,106 & 2,956 & $6,260^{\mathrm{d}}$ \\
\hline
\end{tabular}

a Difference in means between low and high R\&D groups significantly different from zero at the $1 \%$ level. All reported averages are significantly different from zero at the $1 \%$ level, using standard error of the mean.

Total number of affiliates summed across groups is greater than the total as MNC parents (Panel A) and countries (Panel B) can change groups. Countries in the sample include: Argentina, Australia, Austria, Belgium, Brazil, Canada, Chile, China, Colombia, Denmark, Finland, France, Germany Greece, Hong Kong, Hungary, India, Indonesia, Ireland, Israel, Italy, Japan, South Korea, Malaysia, Mexico, Netherlands, New Zealand, Norway, Peru, Philippines, Poland, Portugal, Singapore, South Africa, Spain, Sweden, Switzerland, Thailand, Turkey, United Kingdom and Venezuela. 
Table II

\section{U.S. MNC Foreign Affiliate Characteristics and R\&D, 1983-1996}

All efficiency variables are industry- and year-adjusted. Affiliate efficiency is a labor value-added measure and is calculated as real affiliate gross product divided by affiliate employment. We calculate parent efficiency as sales less cost of goods sold divided by parent employment. Percentages of total debt from the parent and local sources do not add up to $100 \%$, because firms can borrow from other countries and from other sources in the U.S. We convert all sales and cost data into 1982 dollars using BLS three-digit industry deflators. Capital market development data is obtained from the IFC. U.S. multinational data is from the Bureau of Economic Analysis.

\begin{tabular}{|c|c|c|c|c|c|c|c|}
\hline & \multicolumn{7}{|c|}{ Sample of Firms } \\
\hline & \multicolumn{3}{|c|}{$\begin{array}{c}\text { MNCs with } \\
\text { Small Number of Affiliates \& }\end{array}$} & \multicolumn{4}{|c|}{$\begin{array}{c}\text { MNCs with } \\
\text { Large Number of Affiliates \& }\end{array}$} \\
\hline & Low R\&D & \multicolumn{2}{|c|}{ High R\&D } & \multicolumn{4}{|c|}{ Low R\&D High R\&D } \\
\hline Affiliate size (median, $1982 \$ 000$ ) & 26,376 & 30,059 & & 30,968 & & 43,645 & \\
\hline MNC parent size (median, $1982 \$ 000$ ) & $1,374,788$ & 741,936 & & $7,038,920$ & & $3,421,576$ & \\
\hline Number of affiliates & 1,242 & 3,262 & & 1,173 & & 3,665 & \\
\hline $\begin{array}{l}\text { Efficiency of affiliate - 50th percentile } \\
\text { relative MNC-industry-year }\end{array}$ & 0.00 & 0.00 & & -3.56 & & -2.16 & \\
\hline $\begin{array}{l}\text { Efficiency of affiliate - 50th percentile } \\
\text { relative country-industry-year }\end{array}$ & 0.00 & -2.71 & & 0.00 & & 0.00 & \\
\hline \multicolumn{8}{|c|}{ For highest efficiency (above 50th percentile) affiliates } \\
\hline Affiliate employee growth rate (average) & $0.40 \%$ & $1.28 \%$ & & $0.00 \%$ & & $0.34 \%$ & \\
\hline MNC Parent Growth Rate (average) & $3.18 \%$ & $2.11 \%$ & c & $1.94 \%$ & d & $3.18 \%$ & $\mathrm{a}, \mathrm{d}$ \\
\hline Efficiency of MNC parent (average) & 31.56 & 14.14 & a & 53.84 & d & 15.29 & $\mathrm{a},-$ \\
\hline Efficiency of other affiliates (average) & 0.37 & 4.29 & a & 4.54 & d & 4.72 & \\
\hline $\mathrm{R} \& \mathrm{D}$ to sales ratio of $\mathrm{MNC}$ parent (average) & $2.0 \%$ & $5.3 \%$ & a & $2.6 \%$ & d & $7.2 \%$ & $\mathrm{a}, \mathrm{d}$ \\
\hline Debt to asset ratio for affiliates (average) & $55.4 \%$ & $49.0 \%$ & a & $62.4 \%$ & d & $54.8 \%$ & $\mathrm{a}, \mathrm{d}$ \\
\hline$\%$ debt from parent (average) & $14.2 \%$ & $19.5 \%$ & a & $12.8 \%$ & d & $15.2 \%$ & $\mathrm{a}, \mathrm{d}$ \\
\hline$\%$ debt from local borrowing (average) & $70.3 \%$ & $65.6 \%$ & a & $66.0 \%$ & d & $63.3 \%$ & $\mathrm{a}, \mathrm{d}$ \\
\hline$\%$ affiliate sales within MNC (average) & $14.8 \%$ & $25.5 \%$ & a & $16.6 \%$ & d & $26.4 \%$ & $\mathrm{a}, \mathrm{d}$ \\
\hline $\begin{array}{l}\% \text { affiliate sales to local parties } \\
\text { (average, outside MNC) }\end{array}$ & $84.9 \%$ & $74.8 \%$ & $\mathrm{a}$ & $85.8 \%$ & & $77.6 \%$ & $\mathrm{a}, \mathrm{d}$ \\
\hline
\end{tabular}

Means are significantly different from zero at the 5\% level or lower using standard error of the mean.

a,c Difference in means between low and high R\&D groups, within size groups, sig. different from zero at the 1\%, $10 \%$ level.

d Difference in means across size groups, for low and high R\&D, significantly different from zero at the $1 \%$ level. 


\section{Table III}

\section{MNC Allocation of Resources by Foreign Affiliate Efficiency}

This table presents affiliate growth by the initial efficiency of the affiliate of U.S. multinational firms. Efficiency and growth rates are country-, industry- and year-adjusted. We determine efficiency quartiles by the median of affiliate's initial efficiency for the first three years they appear in the database. We then track the growth in the number of employees for the next nine years, until 1996 or until they exit the database. In Panel A, we present affiliate growth rates for the top and bottom quartiles of initial efficiency. In Panel $\mathrm{B}$, we focus on those firms in the highest two and lowest two quartiles of financial-market development. Financial-market development quartiles are determined by ranking countries by their stock market capitalization in each year. We obtain multinational affiliate data from the Bureau of Economic Analysis and financial-market development data from the IFC.

\begin{tabular}{|c|c|c|c|c|}
\hline \multicolumn{5}{|c|}{$\begin{array}{l}\text { Panel A: Affiliate Growth in Employment } \\
\text { Years after three year beginning period }\end{array}$} \\
\hline & Year +1 & Year +3 & Year +5 & Year +9 \\
\hline \multicolumn{5}{|c|}{$\begin{array}{l}\text { Growth rate of affiliate division } \\
\text { By quartile of initial efficiency } \\
\text { (Quartile } 1 \text { is lowest efficiency quartile) }\end{array}$} \\
\hline $\begin{array}{r}\text { Quartile 1: Firm growth rate } \\
\text { Number of affiliates }\end{array}$ & $\begin{array}{r}-1.58 \% \\
788\end{array}$ & $\begin{array}{c}-0.99 \% \\
478\end{array}$ & $\begin{array}{c}-0.43 \% \\
293\end{array}$ & $\begin{array}{c}-3.68 \% \\
57\end{array}$ \\
\hline $\begin{array}{l}\text { Quartile 4: Firm growth rate } \\
\text { Number of affiliates }\end{array}$ & $\begin{array}{c}2.38 \%^{\mathrm{a}} \\
927\end{array}$ & $\begin{array}{l}5.49 \%^{\mathrm{a}} \\
640\end{array}$ & $\begin{array}{l}7.32 \%{ }^{a} \\
387\end{array}$ & $\begin{array}{l}8.43 \%^{b} \\
174\end{array}$ \\
\hline
\end{tabular}

Panel B: Affiliate Growth in Employment by Financial-Market Development Quartiles

Years after three year beginning period

\begin{tabular}{|c|c|c|c|c|}
\hline & Year +1 & Year +3 & Year +5 & Year +9 \\
\hline \multicolumn{5}{|c|}{ Efficiency Quartiles in countries with low capital market developmen1 } \\
\hline Quartile 1: Firm growth rate & $-4.06 \%$ b & $-9.92 \%{ }^{b}$ & $-1.94 \%$ & $0.56 \%$ \\
\hline Number of affiliates & 239 & 123 & 74 & 18 \\
\hline Quartile 4: Firm growth rate & $2.17 \%$ & $3.49 \%$ & $9.20 \%^{\mathrm{a}}$ & $22.19 \%^{\mathrm{a}}$ \\
\hline Number of affiliates & 298 & 158 & 123 & 33 \\
\hline \multicolumn{5}{|c|}{ Efficiency Quartiles in countries with high capital market development } \\
\hline Quartile 1: Firm growth rate & $-0.38 \%$ & $2.13 \%$ & $-2.16 \%$ & $-5.56 \%$ \\
\hline Number of affiliates & 540 & 351 & 216 & 38 \\
\hline Quartile 4: Firm growth rate & $2.49 \% \mathrm{~b}$ & $6.61 \%^{\mathrm{a}}$ & $6.94 \%{ }^{\mathrm{a}}$ & $4.07 \%$ \\
\hline Number of affiliates & 624 & 478 & 260 & 75 \\
\hline
\end{tabular}

a,b,c indicates significant change from year 0 at the $1 \%, 5 \%$, and $10 \%$ levels, respectively. 
Table IV

\section{Growth of MNC Affiliates}

This table presents regressions of affiliate growth in employment on affiliate efficiency and demand changes. Affiliate efficiency variables are lagged and industry- and year-adjusted. Affiliate efficiency is a labor value-added measure and is calculated as real affiliate gross product divided by affiliate employment. We calculate parent efficiency as as sales less cost of goods sold divided by parent employment. MNC integration is the percentage of affiliate sales exported to and imported from the rest of the MNC. High (low) parent R\&D represent the top (bottom) 50th of R\&D at the MNC parent level. Exchange rate (GDP) change is the log change in year-end exchange rates (GDP). Relative GDP changes are relative to the MNC's other affiliates. The local effective tax rate is the median taxes paid over taxable income by country, industry, and year for all affiliates. All regressions contain a time trend, random firm effects, and country dummy variables. All coefficients and standard errors for efficiency variables are multiplied by 1,000 . (Standard errors are in parentheses.)

\begin{tabular}{ccc} 
& Low Parent & High Parent \\
All Affiliates & R\&D & R\&D \\
\hline
\end{tabular}

\section{Affiliate Efficiency Variables}

Efficiency - relative MNC-industry-year

Efficiency - relative country-industry-year

Key Intra-MNC Trade-off Variables

Relative efficiency (MNC-Ind-Year)*GDP change

Efficiency of U.S. parent * relative GDP change of U.S parent

Efficiency of other affiliates * relative GDP change of of other affiliates

\section{MNC and Country Control Variables}

Efficiency of US parent

Efficiency of other affiliates in the MNC

Affiliate MNC integration (lagged) (coefficient*100)

Log sales (lagged)

Exchange rate change

GDP change

Long-run (5-year) GDP growth

Relative GDP change of other affiliates

Relative GDP change of U.S. parent

Local effective tax rate

Trend

Constant

$p$-value for $X^{2}$ test of joint significance of variables

Number of observations

Number of affiliates

${ }_{\mathrm{a}, \mathrm{b}, \mathrm{c}}$ significantly different from 0 at the $1 \%, 5 \%$, and $10 \%$ levels, respectively.

$\begin{array}{lcc}0.116^{\mathrm{a}} & 0.085 & 0.112^{\mathrm{c}} \\ (0.05) & (0.07) & (0.06) \\ 0.157^{\mathrm{a}} & 0.102^{\mathrm{b}} & 0.218^{\mathrm{a}} \\ (0.03) & (0.05) & (0.04)\end{array}$

$\begin{array}{ccc}5.999^{\mathrm{a}} & 4.679^{\mathrm{b}} & 6.539^{\mathrm{a}} \\ (1.34) & (2.37) & (1.68) \\ -0.692 & 0.530 & -1.332^{\mathrm{b}} \\ (0.45) & (0.81) & (0.57) \\ -3.533^{\mathrm{b}} & -5.938^{\mathrm{c}} & -2.259 \\ (1.66) & (3.28) & (1.94)\end{array}$

$\begin{array}{lll}0.033^{\mathrm{b}} & -0.005 & 0.054^{\mathrm{b}}\end{array}$

$\begin{array}{lll}(0.02) & (0.04) & (0.03)\end{array}$

$0.261^{\text {a }} \quad 0.288^{\text {a }} \quad 0.213^{\text {a }}$

$\begin{array}{lll}(0.05) & (0.09) & (0.07)\end{array}$

$\begin{array}{lll}0.881 & -0.349 & 1.107\end{array}$

$\begin{array}{lll}(0.91) & (2.80) \quad(0.92)\end{array}$

$\begin{array}{ccc}-0.015^{\mathrm{a}} & -0.016^{\mathrm{a}} & -0.013^{\mathrm{a}} \\ & \end{array}$

$\begin{array}{lll}(0.00) & (0.00) & (0.00)\end{array}$

$\begin{array}{lll}-0.004 & 0.026 & -0.021\end{array}$

$\begin{array}{lll}(0.02) & (0.48) & (0.02)\end{array}$

$\begin{array}{lll}0.568^{\mathrm{a}} & 0.261 & 0.684^{\mathrm{a}}\end{array}$

$\begin{array}{lll}(0.15) & (0.33) & (0.16)\end{array}$

$\begin{array}{lll}0.121^{\text {a }} & 0.068 & 0.123^{\text {a }}\end{array}$

$\begin{array}{lll}(0.03) & (0.08) & (0.03)\end{array}$

$\begin{array}{lll}0.235^{\mathrm{b}} & 0.256 & 0.215^{\mathrm{c}}\end{array}$

$\begin{array}{lll}(0.11) & (0.26) & (0.12)\end{array}$

$\begin{array}{lll}0.176 & -0.366 & 0.329^{\text {a }}\end{array}$

$\begin{array}{lll}(0.11) & (0.27) & (0.12)\end{array}$

$\begin{array}{ccc}-0.056^{\mathrm{c}} & -0.300^{\mathrm{a}} & 0.004 \\ (0.3) & (0.08)\end{array}$

$\begin{array}{lll}(0.03) & (0.08) & (0.03)\end{array}$

$\begin{array}{ccc}-0.001^{\mathrm{b}} & -0.001 & -0.001^{\mathrm{c}}\end{array}$

$\begin{array}{lll}(0.00) & (0.00) & (0.00)\end{array}$

$\begin{array}{lll}0.121^{\text {a }} & 0.202^{\text {a }} & 0.084^{\text {a }}\end{array}$

$\begin{array}{lll}(0.02) & (0.05) & (0.03)\end{array}$

$\begin{array}{rrr}0.00 & 0.00 & 0.00 \\ 34384 & 8150 & 26557\end{array}$

$\begin{array}{lll}8106 & 2173 & 6014\end{array}$ 
Table V

\section{Effect of Size and R\&D}

This table presents regressions of affiliate growth in employment on affiliate efficiency and demand changes. Efficiency variables are lagged and industry- and year-adjusted. Affiliate efficiency is a labor value-added measure and calculated as real affiliate gross product divided by affiliate employment. We calculate parent efficiency as sales less cost of goods sold divided by parent employment. MNC integration is the percentage of affiliate sales exported to and imported from the rest of the MNC. Low (high) R\&D and small (large) number of affiliates represent the bottom (top) 50th percentile of each variable. Exchange rate (GDP) change is the log change in year end exchange rates (GDP). Relative GDP changes are relative to the MNC's other affiliates. The local effective tax rate is the median taxes paid over taxable income by country, industry, and year for all affiliates. All regressions contain a time trend, random firm effects, and country dummy variables. All affiliate- and MNC-level variables are lagged. All coefficients and standard errors for efficiency variables are multiplied by 1,000. (Standard errors are in parentheses.)

\section{Affiliate Efficiency Variables}

Efficiency - relative MNC-industry-year

Efficiency - relative country-industry-year

Key Intra-MNC Trade-off Variables

Relative efficiency (MNC-Ind-Year)*GDP change

Efficiency of U.S. parent * relative GDP change of U.S. parent

Efficiency of other affiliates * relative GDP change o of other affiliates

\section{MNC and Country Control Variables}

Efficiency of US parent

Efficiency of other affiliates in the MNC

Affiliate MNC integration (lagged) (coefficient*100)

Log sales (lagged)

Exchange rate change

GDP change

Long-run (5-year) GDP growth

Relative GDP change of other affiliates

Relative GDP change of U.S. parent

Local effective tax rate

Trend

Constant

$p$-value for $X^{2}$ test of joint significance of variables

Number of observations

Number of affiliates

\subsection{7}

(0.13)

0.038

(0.07)

$9.692^{\mathrm{a}}$
$(3.43)$
1.346
$(1.18)$
$-8.536^{\mathrm{b}}$
$(3.89)$

0.021

$(0.05)$

$0.332^{\mathrm{a}}$

(0.09)

$-1.894$

(3.12)

$-0.021^{\mathrm{a}}$

$(0.01)$

0.023

$(0.07)$

0.302

$(0.42)$

0.089

$(0.10)$

0.105

$(0.30)$

$-0.235$

(0.36)

$-0.380^{\mathrm{a}}$

$(0.10)$

$0.005^{\mathrm{b}}$

$(0.00)$

$0.230^{\mathrm{a}}$

(0.07)

0.00

4121

1242

$0.351^{\mathrm{a}}$
$(0.12)$
$0.184^{\mathrm{a}}$
$(0.07)$

0.104

(0.09)

$0.137^{\mathrm{b}}$

(0.07)

$7.854^{\mathrm{a}}$

(3.05)

$-1.941^{b}$

(0.94)

$-7.840^{\mathrm{a}}$

(2.66)

$-0.597$

(3.41)

0.003

(1.13)

$-1.347$

(5.98)

0.045

$(0.04)$

$0.320^{\mathrm{a}}$

(0.09)

$-0.678$

(1.44)

$-0.020^{\mathrm{a}}$

$(0.00)$

$-0.033$

(0.03)

$1.043^{\mathrm{a}}$

$(0.23)$

0.030

$(0.05)$

0.177

(0.15)

$0.563^{\mathrm{a}}$

$(0.18)$

0.035

$(0.05)$

$-0.001^{\mathrm{a}}$

$(0.00)$

$0.142^{b}$

(0.05)

0.00

11432

3262

\section{$-0.065$}

(0.06)

$0.447^{\circ}$

$(0.25)$

0.707

(4.77)

$-0.009$

(0.007)

$-0.042$

(0.07)

0.243

$(0.60)$

0.060

(0.12)

0.274

(0.49)

$-0.311$

(0.42)

$-0.188$

(0.12)

$-0.004^{\circ}$

$(0.00)$

$0.148^{\mathrm{c}}$

(0.08)

0.00

3656

1173
0.044

(0.07)

$0.223^{\mathrm{a}}$

(0.06)

$5.306^{\mathrm{a}}$

(2.03)

$-1.218$

(0.73)

3.191

(2.87)

$0.063^{\mathrm{c}}$

(0.04)

0.143

(0.13)

$2.068^{\mathrm{c}}$

(1.22)

$-0.011^{\mathrm{a}}$

$(0.00)$

$-0.007$

$(0.02)$

$0.482^{\mathrm{c}}$

(0.24)

$0.170^{\text {a }}$

$(0.04)$

0.264

(0.21)

0.166

(0.16)

$-0.008$

$(0.04)$

$-0.001$

$(0.00)$

$0.068^{\mathrm{b}}$

$(0.03)$

0.00

15125

3665

a,b,c significantly different from 0 at the $1 \%, 5 \%$, and $10 \%$ levels, respectively. 
Table VI

\section{Affifliate Financing}

This table presents regressions of affiliate growth in employment on affiliate efficiency and demand changes. Efficiency variables are lagged and industry- and year-adjusted. Affiliate efficiency is a labor value-added measure calculated as real affiliate gross product divided by affiliate employment. We calculate parent efficiency as sales less cost of goods sold divided by parent employment. MNC integration is the percentage of affiliate sales exported to and imported from the rest of the MNC. Low (high) financing and small (large) number of affiliates represent the bottom (top) 50th percentile of each variable (lagged). Exchange rate (GDP) is the log change in year-end exchange rates (GDP). Relative GDP changes are relative to the MNC's other affiliates. The local effective tax rate is the median taxes paid over taxable income by country, industry, and year for all affiliates. All regressions contain a time trend, random firm effects, and country dummy variables. All affiliate- and MNC-level variables are lagged. All coefficients and standard errors for efficiency variables are multiplied by 1,000. (Standard errors are in parentheses.)

Small Number of Affiliates

$$
\text { Low High }
$$

Local \& Parent Financing
Large Number of Affiliates

$$
\text { Low High }
$$

Local \& Parent Financing

\section{Affiliate Efficiency Variables}

Efficiency - relative MNC-industry-year

$\begin{array}{llll}0.097 & 0.253^{\mathrm{c}} & -0.073 & 0.178^{\mathrm{a}} \\ (0.12) & (0.13) & (0.09) & (0.07) \\ 0.108^{\mathrm{c}} & 0.172^{\mathrm{a}} & 0.222^{\mathrm{a}} & 0.129^{\mathrm{b}} \\ (0.06) & (0.07) & (0.06) & (0.05)\end{array}$

Efficiency - relative country-industry-year

$$
\text { (0.06) }
$$

$9.933^{\mathrm{a}}$

(2.98)

Efficiency of U.S. parent * relative GDP change of U.S. parent

Efficiency of other affiliates * relative GDP change of of other affiliates

$-0.509$

(1.07)

$-11.194^{a}$

(2.98)

\section{MNC and Country Control Variables}

Efficiency of US parent

Efficiency of other affiliates in the MNC

Affiliate MNC integration (lagged)

(coefficient*100)

Log sales (lagged)

Exchange rate change

GDP change

Long-run (5-year) GDP growth

Relative GDP change of other affiliates

Relative GDP change of U.S. parent

Local effective tax rate

Trend

Constant

$p$-value for $X^{2}$ test of joint significance of variables

Number of observations

Number of affiliates

\begin{tabular}{cccc}
0.040 & 0.059 & -0.031 & 0.027 \\
$(0.05)$ & $(0.04)$ & $(0.05)$ & $(0.04)$ \\
$0.256^{\mathrm{a}}$ & $0.304^{\mathrm{a}}$ & -0.016 & $0.438^{\mathrm{a}}$ \\
$(0.08)$ & $(0.10)$ & $(0.19)$ & $(0.15)$ \\
0.457 & -0.483 & -0.072 & $3.842^{\mathrm{b}}$ \\
$(1.74)$ & $(1.99)$ & $(1.92)$ & $(1.57)$ \\
$-0.014^{\mathrm{a}}{ }^{\mathrm{a}}$ & $-0.018^{\mathrm{a}}$ & -0.002 & $-0.019^{\mathrm{a}}$ \\
$(0.00)$ & $(0.005)$ & $(0.004)$ & $(0.00)$ \\
-0.030 & 0.011 & -0.016 & -0.026 \\
$(0.04)$ & $(0.04)$ & $(0.03)$ & $(0.03)$ \\
$0.973^{\mathrm{a}}$ & $0.668^{\mathrm{a}}$ & $0.593^{\mathrm{c}}$ & $0.267^{\mathrm{c}}$ \\
$(0.28)$ & $(0.29)$ & $(0.34)$ & $(0.29)$ \\
0.056 & 0.026 & 0.063 & $0.256^{\mathrm{a}}$ \\
$(0.07)$ & $(0.07)$ & $(0.06)$ & $(0.05)$ \\
$0.333^{\mathrm{c}}$ & 0.167 & 0.203 & 0.355 \\
$(0.19)$ & $(0.20)$ & $(0.29)$ & $(0.25)$ \\
0.307 & 0.304 & 0.291 & -0.076 \\
$(0.24)$ & $(0.22)$ & $(0.24)$ & $(0.19)$ \\
-0.017 & -0.063 & 0.081 & $-0.104^{\mathrm{c}}$ \\
$(0.06)$ & $(0.08)$ & $(0.06)$ & $(0.06)$ \\
0.002 & -0.002 & $-0.003^{\mathrm{c}}$ & -0.001 \\
$(0.00)$ & $(0.00)$ & $(0.00)$ & $(0.00)$ \\
0.079 & $0.157^{\mathrm{a}}$ & -0.057 & $0.217^{\mathrm{a}}$ \\
$(0.05)$ & $(0.06)$ & $(0.05)$ & $(0.04)$ \\
\hline 0.00 & 0.00 & 0.00 & 0.00 \\
7710 & 7728 & 8520 & 10181 \\
2838 & 2940 & 2962 & 3356 \\
\hline
\end{tabular}

${ }^{\mathrm{a}, \mathrm{b}, \mathrm{c}}$ significantly different from 0 at the $1 \%, 5 \%$, and $10 \%$ levels, respectively.

$\begin{array}{ccc}10.790^{\mathrm{a}} & 3.968 & 3.487^{\mathrm{c}} \\ (3.69) & (2.67) & (2.17) \\ -0.835 & -0.777 & -1.084 \\ (0.89) & (0.88) & (0.77) \\ -4.482 & 1.186 & 1.164 \\ (3.61) & (4.09) & (3.21)\end{array}$

1.164 
Table VIb

\section{Economic Significance of Regression Results}

This table presents the predicted annual employee growth rate using the coefficient estimates from Table VI, columns one to four as indicated. We vary productivity and demand interaction variables from the 10th to the 90 th percentiles. All other variables are held at the medians for the respective samples. Country dummy variables vary with the respective observation.

Varying Affiliate (own) Efficiency \& Demand Interaction Variable

\begin{tabular}{|c|c|c|c|c|c|}
\hline $\begin{array}{l}\text { Affiliate Efficiency \& Demand Interaction } \\
\text { at the: }\end{array}$ & $\begin{array}{c}10 \text { th } \\
\text { Percentile }\end{array}$ & $\begin{array}{c}25 \text { th } \\
\text { Percentile }\end{array}$ & $\begin{array}{l}\text { Median } \\
\text { Level }\end{array}$ & $\begin{array}{c}\text { 75th } \\
\text { Percentile }\end{array}$ & $\begin{array}{c}\text { 90th } \\
\text { Percentile }\end{array}$ \\
\hline \multicolumn{6}{|l|}{ MNCs with small affiliate networks } \\
\hline \& low use of parent/local financing (column 1) & $-1.49 \%$ & $-0.42 \%$ & $0.03 \%$ & $0.42 \%$ & $1.47 \%$ \\
\hline$\&$ high use of parent/local financing (column 2) & $-2.71 \%$ & $-0.98 \%$ & $-0.16 \%$ & $0.35 \%$ & $1.74 \%$ \\
\hline \multicolumn{6}{|l|}{ MNCs with large affiliate networks } \\
\hline \& low use of parent/local financing (column 3 ) & $-2.62 \%$ & $-1.82 \%$ & $-1.52 \%$ & $-1.26 \%$ & $-0.57 \%$ \\
\hline$\&$ high use of parent/local financing (column 4) & $-2.57 \%$ & $-1.17 \%$ & $-0.39 \%$ & $0.05 \%$ & $1.11 \%$ \\
\hline \multicolumn{6}{|c|}{ Varying Other Affiliate \& Parent Interaction Demand Variables } \\
\hline $\begin{array}{l}\text { Other Affiliate \& Parent Interaction Variables } \\
\text { at the: }\end{array}$ & $\begin{array}{c}\text { 10th } \\
\text { Percentile }\end{array}$ & $\begin{array}{c}25 \text { th } \\
\text { Percentile }\end{array}$ & $\begin{array}{l}\text { Median } \\
\text { Level }\end{array}$ & $\begin{array}{c}\text { 75th } \\
\text { Percentile }\end{array}$ & $\begin{array}{c}\text { 90th } \\
\text { Percentile }\end{array}$ \\
\hline \multicolumn{6}{|l|}{ MNCs with small affiliate networks } \\
\hline$\&$ low use of parent/local financing (column 1) & $0.84 \%$ & $0.23 \%$ & $0.03 \%$ & $-0.16 \%$ & $-0.76 \%$ \\
\hline$\&$ high use of parent/local financing (column 2) & $0.17 \%$ & $-0.06 \%$ & $-0.16 \%$ & $-0.23 \%$ & $-0.46 \%$ \\
\hline \multicolumn{6}{|l|}{ MNCs with large affiliate networks } \\
\hline$\&$ low use of parent/local financing (column 3) & $-1.42 \%$ & $-1.50 \%$ & $-1.52 \%$ & $-1.54 \%$ & $-1.61 \%$ \\
\hline$\&$ high use of parent/local financing (column 4) & $-0.25 \%$ & $-0.35 \%$ & $-0.39 \%$ & $-0.43 \%$ & $-0.57 \%$ \\
\hline
\end{tabular}


Table VII

Source of Affiliate Financing and Financial Market Development

This table presents regressions of affiliate growth in employment on affiliate efficiency and demand changes. All efficiency variables are lagged and industry- and year-adjusted. Affiliate efficiency is a labor value-added measure and is calculated as real affiliate gross product divided by affiliate employment. We calculate parent efficiency as sales less cost of goods sold divided by parent employment. MNC integration is the percentage of affiliate sales exported to and imported from the rest of the MNC. Low (high) market capitalization and small (large) number of affiliates represent the bottom (top) 50th percentile of each variable. Exchange rate (GDP) change is the log change in year end exchange rates (GDP). Relative GDP changes are relative to the MNC's other affiliates. The local effective tax rate is the median taxes paid over taxable income by country, industry, and year for all affiliates. All affiliate- and firm-specific variables are lagged one period. All regressions contain a time trend, random firm effects, and country dummy variables. All coefficients and standard errors for efficiency variables are multiplied by 1,000. (Standard errors are in parentheses.)

Low Stock Market Capitalization

Small Number of Affiliates $\quad$ Large Number of Affiliates

$\begin{array}{lcc}\text { Affiliate Efficiency Variables } & & \\ \text { Efficiency - relative MNC-industry-year } & 0.058 & 0.018^{\mathrm{b}} \\ & (0.17) & (0.08) \\ \text { Efficiency - relative country-industry-year } & 0.658^{\mathrm{a}} & 0.162 \\ & (0.13) & (0.08) \\ & & \\ \text { Key Intra-MNC Trade-off Variables } & 6.370^{\mathrm{c}} & 3.749^{\mathrm{c}} \\ \text { Relative Efficiency (MNC-Ind-Year)*GDP change } & (3.85) & (2.08) \\ \text { Percentage parent debt financing } & 0.025 & -0.022 \\ & (0.03) & (0.03) \\ & & \\ \text { Efficiency of U.S. Parent * relative GDP change of } & -1.499 & -1.547^{\mathrm{c}} \\ \text { U.S. parent } & (1.23) & (0.87) \\ \text { Interacted with \% parent debt financing } & -12.326^{\mathrm{b}} & -3.190 \\ & (6.64) & (4.06) \\ \text { Efficiency of other affiliates * relative GDP change } & -5.307 & 5.266 \\ \quad \text { of other affiliates } & (3.88) & (3.81)\end{array}$

\section{MNC and Country Control Variables}

\begin{tabular}{|c|c|c|}
\hline Efficiency of US parent & $\begin{array}{r}-0.061 \\
(0.07)\end{array}$ & $\begin{array}{l}0.019 \\
(0.05)\end{array}$ \\
\hline Efficiency of other affiliates in the MNC & $\begin{array}{r}0.231 \\
(0.16)\end{array}$ & $\begin{array}{r}0.176 \\
(0.20)\end{array}$ \\
\hline $\begin{array}{l}\text { Affiliate MNC integration (lagged) } \\
\text { (coefficient*100) }\end{array}$ & $\begin{array}{l}-4.720^{c} \\
(2.80)\end{array}$ & $\begin{array}{l}3.517 \\
(2.31)\end{array}$ \\
\hline Log sales (lagged) & $\begin{array}{r}-0.010 \\
(0.01)\end{array}$ & $\begin{array}{l}-0.012^{\mathrm{b}} \\
(0.005)\end{array}$ \\
\hline Exchange rate change & $\begin{array}{l}0.031 \\
(0.04)\end{array}$ & $\begin{array}{r}-0.028 \\
(0.03)\end{array}$ \\
\hline GDP change & $\begin{array}{l}1.111^{\mathrm{b}} \\
(0.46)\end{array}$ & $\begin{array}{l}0.483 \\
(0.36)\end{array}$ \\
\hline Long-run (5-year) GDP growth & $\begin{array}{l}0.201^{\mathrm{b}} \\
(0.08)\end{array}$ & $\begin{array}{l}0.273^{\mathrm{a}} \\
(0.07)\end{array}$ \\
\hline Relative GDP change of other affiliates & $\begin{array}{l}1.116^{\mathrm{a}} \\
(0.28)\end{array}$ & $\begin{array}{l}0.627^{\mathrm{b}} \\
(0.30)\end{array}$ \\
\hline Relative GDP change of U.S. parent & $\begin{array}{l}-0.260 \\
(0.35)\end{array}$ & $\begin{array}{l}-0.099 \\
(0.25)\end{array}$ \\
\hline Effective local tax rate & $\begin{array}{l}-0.212^{b} \\
(0.09)\end{array}$ & $\begin{array}{l}-0.104^{\mathrm{c}} \\
(0.07)\end{array}$ \\
\hline Trend & $\begin{array}{l}0.002 \\
(0.00)\end{array}$ & $\begin{array}{r}-0.002 \\
(0.00)\end{array}$ \\
\hline Constant & $\begin{array}{r}-0.022 \\
(0.31) \\
\end{array}$ & $\begin{array}{r}0.053 \\
(0.15) \\
\end{array}$ \\
\hline$p$-value for $X^{2}$ test of joint significance of variables & 0.00 & 0.00 \\
\hline Number of observations & 3748 & 6504 \\
\hline Number of affiliates & 1392 & 1939 \\
\hline
\end{tabular}

${ }_{\mathrm{a}, \mathrm{b}, \mathrm{c}}$ significantly different from 0 at the $1 \%, 5 \%$, and $10 \%$ levels, respectively. 
Table VIII

Contracting Effectiveness

This table presents regressions of affiliate growth in employment on affiliate efficiency and contracting effectiveness. Contracting effectiveness is an annual country-level index of the ability to enforce and write contracts. Affiliate efficiency variables are lagged and industry- and year-adjusted. Affiliate efficiency is a labor value-added measure and is calculated as real affiliate gross product divided by affiliate employment. We calculate parent efficiency as sales less cost of goods sold divided by parent employment. MNC integration is the percentage of affiliate sales exported to and imported from the rest of the MNC (lagged), with the top 25th percentile the cutoff for high MNC integration. Low (high) stock market capitalization represents the bottom (top) 50th percentile of stock market capitalization/GDP. Exchange rate (GDP) change is the log change in year end exchange rates (GDP). Relative GDP changes are relative to the MNC's other affiliates. The local effective tax rate is the median taxes paid over taxable income by country, industry, and year for all affiliates. Affiliate- and MNC-level variables are lagged. All regressions contain a time trend and random firm effects. All coefficients and standard errors for the efficiency variables are multiplied by 1,000. (Standard errors are in parentheses.)

\section{Low Stock Market Capitalization \\ High Stock \\ All Affiliates MNC Trade MNC Trade Capitalization}

\begin{tabular}{|c|c|c|c|c|}
\hline \multicolumn{5}{|l|}{ Affiliate Efficiency Variables } \\
\hline \multirow[t]{2}{*}{$\overline{\text { Efficiency - relative MNC-industry-year }}$} & -0.013 & -0.027 & 0.125 & $0.141^{\mathrm{b}}$ \\
\hline & $(0.08)$ & $(0.09)$ & $(0.17)$ & $(0.06)$ \\
\hline \multirow[t]{2}{*}{ Efficiency - relative country-industry-year } & $0.318^{\mathrm{a}}$ & $0.332^{\mathrm{a}}$ & 0.198 & $0.096^{\mathrm{a}}$ \\
\hline & $(0.07)$ & $(0.08)$ & $(0.15)$ & $(0.04)$ \\
\hline \multicolumn{5}{|l|}{ Key Intra-MNC Trade-off Variables } \\
\hline \multirow[t]{2}{*}{ 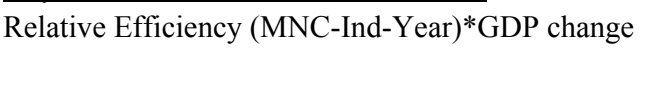 } & $5.610^{\mathrm{b}}$ & $5.662^{\mathrm{b}}$ & 5.002 & $5.899^{\mathrm{a}}$ \\
\hline & $(2.29)$ & $(2.69)$ & $(4.20)$ & $(1.79)$ \\
\hline \multirow{2}{*}{$\begin{array}{c}\text { Efficiency of U.S. Parent * relative GDP change of } \\
\text { U.S. parent }\end{array}$} & $-1.697^{b}$ & -1.149 & $-4.136^{\mathrm{a}}$ & -0.289 \\
\hline & $(0.71)$ & $(0.81)$ & $(1.50)$ & $(0.67)$ \\
\hline \multirow{2}{*}{$\begin{array}{l}\text { Efficiency of other affiliates } * \text { relative GDP change } \\
\text { of other affiliates }\end{array}$} & 1.313 & 0.485 & 1.193 & $-7.148^{a}$ \\
\hline & $(2.96)$ & $(3.52)$ & $(5.34)$ & $(2.21)$ \\
\hline \multicolumn{5}{|l|}{ MNC and Country Control Variables } \\
\hline \multirow[t]{2}{*}{ Index of Contracting Effectiveness (country level) } & $0.006^{\mathrm{b}}$ & $0.007^{b}$ & 0.006 & -0.003 \\
\hline & $(0.002)$ & $(0.003)$ & $(0.004)$ & $(0.00)$ \\
\hline \multirow[t]{2}{*}{ Efficiency of US parent } & -0.011 & 0.000 & -0.073 & $0.059^{\mathrm{b}}$ \\
\hline & $(0.04)$ & $(0.05)$ & $(0.08)$ & $(0.03)$ \\
\hline \multirow[t]{2}{*}{ Efficiency of other affiliates in the MNC } & $0.224^{\mathrm{c}}$ & 0.231 & 0.127 & $0.321^{\mathrm{a}}$ \\
\hline & $(0.13)$ & $(0.15)$ & $(0.24)$ & $(0.06)$ \\
\hline \multirow{2}{*}{$\begin{array}{l}\text { Affiliate MNC integration (lagged) } \\
\text { (coefficient*100) }\end{array}$} & -0.460 & $-19.988^{a}$ & $6.280^{\mathrm{b}}$ & 0.075 \\
\hline & $(1.77)$ & $(5.59)$ & $(2.63)$ & $(1.01)$ \\
\hline \multirow[t]{2}{*}{ Log sales (lagged) } & -0.004 & -0.006 & 0.002 & $-0.010^{a}$ \\
\hline & $(0.00)$ & $(0.00)$ & $(0.006)$ & $(0.00)$ \\
\hline \multirow[t]{2}{*}{ Exchange rate change } & -0.009 & -0.028 & -0.014 & -0.002 \\
\hline & $(0.03)$ & $(0.03)$ & $(0.04)$ & $(0.03)$ \\
\hline \multirow[t]{2}{*}{ GDP change } & $0.631^{\mathrm{b}}$ & 0.558 & 0.709 & $0.569^{\mathrm{a}}$ \\
\hline & $(0.29)$ & $(0.36)$ & $(0.51)$ & $(0.18)$ \\
\hline \multirow[t]{2}{*}{ Long-run (5-year) GDP growth } & $0.271^{\mathrm{a}}$ & $0.294^{\mathrm{a}}$ & $0.247^{\mathrm{a}}$ & $0.129^{\mathrm{a}}$ \\
\hline & $(0.05)$ & $(0.06)$ & $(0.09)$ & $(0.04)$ \\
\hline \multirow[t]{2}{*}{ Relative GDP change of other affiliates } & $0.783^{\text {a }}$ & $0.670^{\mathrm{b}}$ & $1.146^{\mathrm{a}}$ & 0.086 \\
\hline & $(0.21)$ & $(0.28)$ & $(0.35)$ & $(0.14)$ \\
\hline \multirow[t]{2}{*}{ Relative GDP change of U.S. parent } & -0.142 & -0.126 & -0.300 & $0.253^{\mathrm{c}}$ \\
\hline & $(0.21)$ & $(0.24)$ & $(0.40)$ & $(0.14)$ \\
\hline \multirow[t]{2}{*}{ Effective local tax rate } & $-0.151^{\mathrm{a}}$ & -0.094 & $-0.343^{\mathrm{a}}$ & -0.004 \\
\hline & $(0.05)$ & $(0.06)$ & $(0.09)$ & $(0.03)$ \\
\hline \multirow[t]{2}{*}{ Trend } & $-0.004^{\mathrm{a}}$ & $-0.005^{a}$ & -0.003 & -0.001 \\
\hline & $(0.00)$ & $(0.00)$ & $(0.00)$ & $(0.00)$ \\
\hline \multirow[t]{2}{*}{ Constant } & 0.001 & 0.019 & -0.047 & $0.105^{\mathrm{a}}$ \\
\hline & $(0.04)$ & $(0.05)$ & $(0.07)$ & $(0.04)$ \\
\hline$p$-value for $X^{2}$ test of joint significance of variables & 0.00 & 0.00 & 0.00 & 0.00 \\
\hline Number of observations & 9401 & 7043 & 2358 & 21342 \\
\hline Number of affiliates & 2715 & 2252 & 1222 & 5657 \\
\hline
\end{tabular}

a,b,c significantly different from 0 at the $1 \%, 5 \%$, and $10 \%$ levels, respectively. 
Table IX

Increases in Stock Market Development

This table presents regressions of affiliate growth for countries with low initial (1983-1985) stock market and high subsequent growth in stock market capitalization over a twelve year period. The sample is divided into two periods, 1983-1989 and 1990-1996. Affiliate efficiency variables are lagged and industry- and year-adjusted. Affiliate efficiency is a labor value-added measure and is calculated as real affiliate gross product divided by affiliate employment. We calculate parent efficiency as sales less cost of goods sold divided by parent employment. Exchange rate (GDP) change is the log change in year-end exchange rates (GDP). Relative GDP changes are relative to the MNC's other affiliates. The local effective tax rate is the median taxes paid over taxable income by country, industry, and year for all affiliates. All regressions contain a time trend, random firm effects and country dummy variables. All coefficients and standard errors for efficiency variables are multiplied by 1,000 .

All affiliate- and MNC-level variables are lagged. (Standard errors are in parentheses.)

Countries with high increase in Stock Market Capitalization divided by GDP

Early Period Late Period

\section{$\underline{\text { Affiliate Efficiency Variables }}$}

Efficiency - relative MNC-industry-year

0.088

$0.262^{\mathrm{b}}$

Efficiency - relative country-industry-year

$(0.09)$

$(0.12)$

$0.302^{\mathrm{b}}$

$0.205^{\mathrm{b}}$

$(0.13)$

$(0.10)$

Key Intra-MNC Trade-off Variables

Relative Efficiency (MNC-Ind-Year)*GDP change

Efficiency of U.S. Parent * relative GDP change of U.S parent

$(1.15)$

$-2.676^{\mathrm{a}}$

$-1.265$

Efficiency of other affiliates * relative GDP change of other affiliates

$(0.42)$

$(0.95)$

1.927

$-3.068$

(1.66)

\section{MNC and Country Control Variables}

Efficiency of US parent

$0.032-0.022$

$(0.08)$

$(0.06)$

Efficiency of other affiliates in the MNC

0.285

$0.596^{\mathrm{a}}$

Log sales (lagged)

$(0.22)$

$(0.18)$

$-0.011^{\mathrm{c}}$

$-0.018^{\mathrm{a}}$

Exchange rate change

$(0.006)$

$(0.006)$

0.036

$-0.043$

GDP change

$(0.03)$

$(0.05)$

0.086

0.463

Long-run (5-year) GDP growth

$(0.51)$

$(0.42)$

$0.467^{\text {a }}$

$0.228^{\mathrm{c}}$

Relative GDP change of other affiliates

(0.11)

$(0.12)$

0.397

0.264

$(0.40)$

(0.33)

Relative GDP change of U.S. parent

$-0.291$

$-0.016$

$(0.44)$

$(0.31)$

Effective local tax rate

$-0.138^{\mathrm{c}}$

$-0.086$

$(0.08)$

$(0.17)$

Trend

Constant

(0.11)

$(0.12)$

$p$-value for $X^{2}$ test of joint significance of variables

0.00

0.00

Number of observations

3209

4627

Number of affiliates

977

1406

${ }_{\mathrm{a}, \mathrm{b}, \mathrm{c}}$ significantly different from 0 at the $1 \%, 5 \%$, and $10 \%$ levels, respectively. 


\section{Table IXb}

\section{Economic Significance of Regression Results for Table IX}

This table presents the predicted annual employee growth rate using the coefficient estimates from Table IX. We vary efficiency and demand interaction variables from the 10th to the 90th percentiles. All other variables are held at the medians for the respective samples. Country dummy variables vary with the respective observation.

Predicted Annual Employee Growth Rates for Countries with High Increases in Stock Market Development

\begin{tabular}{|c|c|c|c|c|c|}
\hline & $\begin{array}{c}\text { 10th } \\
\text { Percentile }\end{array}$ & $\begin{array}{c}25 \text { th } \\
\text { Percentile }\end{array}$ & $\begin{array}{c}\text { Median } \\
\text { Level }\end{array}$ & $\begin{array}{c}\text { 75th } \\
\text { Percentile }\end{array}$ & $\begin{array}{c}\text { 90th } \\
\text { Percentile }\end{array}$ \\
\hline \multicolumn{6}{|c|}{ Varying Affiliate (own) Efficiency \& Demand Interaction Variable } \\
\hline Early years (1984-1989) & $-0.77 \%$ & $0.03 \%$ & $0.38 \%$ & $0.58 \%$ & $1.25 \%$ \\
\hline Late years (1990-1996) & $-4.31 \%$ & $-1.91 \%$ & $-0.42 \%$ & $0.39 \%$ & $2.18 \%$ \\
\hline \multicolumn{6}{|c|}{ Varying Other Affiliate \& Parent Interaction Demand Variables } \\
\hline Early years (1984-1989) & $0.76 \%$ & $0.50 \%$ & $0.38 \%$ & $-0.23 \%$ & $-1.67 \%$ \\
\hline Late years (1990-1996) & $0.19 \%$ & $-0.25 \%$ & $-0.42 \%$ & $-0.57 \%$ & $-0.98 \%$ \\
\hline
\end{tabular}

